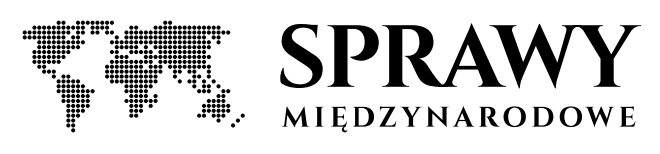

2019 , t. 72 , nr 4

ISSN 0038-853X

DOI:10.35757/SM.2019.72.4.10

BEZPIECZEŃSTWO I POLITYKA ZAGRANICZNA

\author{
MICHAL SLOWIKOWSKI
}

Uniwersytet Łódzki

ORCID: 0000-0001-5202-5080

\title{
Ewolucja polityki Federacji Rosyjskiej wobec Białorusi w kontekście wysiłków integracyjnych w ramach Państwa Związkowego
}

\section{The evolution of the Russian Federation's policy towards Belarus in the context of integration efforts within the Union State's}

Despite expectations, 2019 did not bring a significant breakthrough in the existing model of Russian-Belarusian relations. The extreme scenario - Russia's seizure of Belarus in the course of the process of 'deeper integration' is highly improbable. This is primarily because the Kremlin is not significantly determined to change the existing legal and international status of Belarus. Moreover, Belarus is determined to defend the bilateral relations with Russia formed in the mid-1990s and does not accept the Kremlin's proposals regarding 'deeper integration', which mean limiting its sovereignty. Belarus is determined to defend itself against Russia's demands, which paradoxically increases the level of social legitimacy of Lukashenko's authoritarian rule. Russia has a wide set of negative tools to influence Minsk (energy blackmail, destabilisation of the political and socio-economic situation), but it has no positive tools. There is also a noticeable lack of internal coherence in the Russian power camp with respect to the future of Belarus. Russia is interested in changing the current model of the bilateral relations in terms of limiting financial losses resulting from the generous subsidy of the Belarusian economy and Minsk's disregard for existing obligations in the area of customs and taxation. However, Moscow intends to achieve this goal neither by seizing Belarus nor by destabilising the Belarusian political regime. The issue of 'deeper integration' of both countries was, from the very beginning, clearly related to other problems that cast a shadow on Russian-Belarusian relations. Therefore, it should be assumed that Russia's intention was to use a 'tax maneuver' to force Belarus to negotiate in the sphere of finance, economy and compliance with Russian customs and tax standards. The most likely scenario for the development of Russian-Belarusian relations assumes maintaining the existing model of relations but, from now on, Belarus will be deprived of a significant part of the 'integration rent'. 
Keywords: Belarus, Russia, Union State, 'deeper integration', Alexandr Lukashenka, Vladimir Putin, scenario planning

Słowa kluczowe: Białoruś, Rosja, Państwo Związkowe, „pogłębiona integracja”, Aleksandr Łukaszenka, Władimir Putin, prognozowanie polityczne

W ciągu ostatnich kilkunastu lat koncepcje rozwoju współpracy rosyjsko-białoruskiej wyraźnie się rozmijały w przypadku każdej ze stron. Jeśli Rosja dążyła do zacieśniania z Białorusią związków gospodarczych, politycznych oraz w dziedzinie obronności, to Mińsk zdawał się być usatysfakcjonowany dotychczasowym statusem stosunków i zyskami płynącymi ze współpracy z Rosją. Pojawiające się w dwustronnych kontaktach sporne kwestie finansowe, czy będąca przedmiotem szczególnej uwagi w tym artykule propozycja ,pogłębienia integracji”, były odbierane przez Białoruś jako szantaż i próba „wchłonięcia” Białorusi ${ }^{1}$.

Bardzo szybko po objęciu urzędu prezydenckiego przez Władimira Putina podjęto próby zdyscyplinowania Aleksandra Łukaszenki oraz uporządkowania sprawy integracji Rosji z Białorusią. Już w 2002 r. rosyjski prezydent dał Łukaszence do zrozumienia, że wizja Państwa Związkowego jako integracji dwóch równorzędnych państw jest nierealistyczna, jeśli wziąć pod uwagę, że „gospodarka białoruska stanowi 3 proc. rosyjskiej”. Putin uczynił wówczas sugestywną aluzję do potencjałów Rosji i Białorusi: ,,muchy oddzielnie, kotlety oddzielnie"2. Dla Mińska był to czytelny sygnał, że Rosja raczej będzie dążyć do inkorporacji Białorusi niż realizacji postanowień dotyczących Państwa Związkowego, ale Łukaszenko postawił sprawę jasno: „Białoruś nigdy nie stanie się 90 podmiotem Federacji Rosyjskiej”’3. Ten etap w stosunkach dwustronnych zaważył na dalszych losach projektu Państwa Związkowego - zostały one zdominowane przez konflikty gospodarcze, targi i szantaże, wojny informacyjne ${ }^{4}$. Stosunki Rosji i Białorusi w zakresie budowy wspólnego

1 Co osobiście podsumował Aleksandr Łukaszenka: „Umiem czytać między wierszami. Rozumiem wszystkie aluzje. Postawmy sprawę jasno: dostaniecie ropę, ale rozmontujcie państwo i wstępujcie w skład Rosji [...]. Rosja gotowa jest wchłonąć Białoruś obwodami, czy w całości?”. Zob. V. Solov’ev, Aleksandr Lukašenko skazal meždu strok, „Kommersant"', 15 XII 2018, nr 232, s. 1.

2 A. Vernidub, Putin zabral u Lukašenko kotlety s muhami, „Gazeta.ru” [online], 20 VI 2002 [dostęp: 24 XI 2019], dostępny w internecie: <https://www.gazeta.ru/2002/06/20/putinzabralu.shtml>.

3 Tamże.

4 W 2004 r. Rosja przestała dostarczać na Białoruś gaz, a w 2007 r. Białoruś zablokowała tranzyt rosyjskiej ropy. W 2009 r. wybuchła tzw. mleczna wojna; w 2010 r. Gazprom ponownie odciął Białoruś od gazu, a NTW na przełomie lat 2010-2011 wyemitował 
państwa nabrały ponownie dynamiki na przełomie lat 2018-2019 i związane były z inicjatywą Kremla na rzecz realizacji koncepcji ,pogłębionej integracji” w stosunkach z Białorusią.

Aktywność obu państw w ramach pogłębionej integracji stanowi dogodny pretekst do podjęcia analizy ewolucji stosunku Rosji do współpracy z Białorusią i działań o charakterze prognostycznym w tym obszarze. Okoliczności towarzyszące negocjacjom integracyjnym dostarczają dodatkowego materiału empirycznego pozwalającego zaprojektować scenariusze najbardziej prawdopodobnych kierunków rozwoju stosunków Moskwa-Mińsk.

W zakresie budowania prognozy, czy też scenariusza, rozwoju stosunków rosyjsko-białoruskich wypada odwołać się do koncepcji Stevena Bernsteina, Richarda Neda Lebowa, Janice Gross Stein i Stevena Webera. Koncepcja ta polega m.in. na zdefiniowaniu ogólnego kontekstu i sił napędowych rozwoju wydarzeń (driving force), np. międzynarodowych, w którym zamierza się budować scenariusze rozwoju zdarzeń (plot lines), określeniu czynników strukturalnych (predetermined elements), trwale obecnych w każdym ze scenariuszy, i w końcu wskazania krytycznych niewiadomych (critical uncertainties $)^{5}$. Ich przecinanie się stanowi podstawę wyodrębniania dopuszczalnych możliwych trajektorii rozwoju dalszej dynamiki stosunków rosyjsko-białoruskich. Koncentrując uwagę na kwestii krytycznych niewiadomych, warto zwrócić uwagę, że mówimy w tym przypadku o „kluczowych zmiennych dotyczących zdarzeń, których charakter, skala lub konsekwencje są nieznane. Ta niewiadoma może być wynikiem nieujawnionych skutków interakcji zachodzących między czynnikami strukturalnymi”. Pomija się przypadki losowe (wild cards), które zdolne są całkowicie unieważnić budowę scenariusza. To, co można by uznać za krytyczną niewiadomą (za Bernsteinem i resztą

pięcioodcinkowy serial dokumentalny Krëstnyj bat'ka, w którym zarzucano Łukaszence m.in. pasożytowanie na Rosji i działalność przestępczą. Rosja przed 2019 r. nie podjęła jednak zdecydowanej próby w sprawie odsunięcia Łukaszenki od władzy, ograniczając się do działań mających „uwrażliwić” białoruskiego prezydenta na negocjacyjne propozycje strony rosyjskiej. Zob. A. Shraibman, The house that Lukashenko built: the foundation, evolution, and future of the Belarusian regime, Carnegie Moscow Center [online], 12 IV 2019 [dostęp: 31 I 2020], dostępny w internecie: <https://carnegie.ru/2018/04/12/ house-that-lukashenko-built-foundation-evolution-and-future-of-belarusian-regimepub-76059>; Û. Drakohrust, Kak Putin ne stal belorusom. Peripetii sbliženiâ sosedej, Radio Svoboda [online], 5 IX 2019 [dostęp: 31 I 2020], dostępny w internecie: <https:// www.svoboda.org/a/30142580.html $>$.

5 S. Bernstein, N. Lebow, J. Gross Stein, S. Weber, God gave physics the easy problems. Adapting social science to an unpredictable world, "European Journal of International Relations" 2000, vol. 7, No. 1, s. 55.

6 Tamże, s. 56. 
autorów koncepcji), to postawa negocjacyjna obydwu stron. Konkretyzując to sformułowanie, należy mieć na myśli gotowość, lub dokładniej, determinację, by utrzymać/zmienić istniejący model stosunków?

Budując scenariusze przyszłości, trzeba w omawianym przypadku określić poziom wspomnianej determinacji. Aby tego dokonać, konieczna jest odpowiedź na następujące pytania $\mathrm{w}$ odniesieniu do stanowiska Białorusi - po pierwsze: dlaczego Białoruś przeciwstawia się rosyjskim planom w zakresie pogłębionej integracji, i po drugie: czy dysponuje zasobami i strategią powstrzymującą presję ze strony Rosji? Nie ma bowiem wątpliwości, że Białoruś pragnie zachowania istniejącego kształtu stosunków, lecz otwartą kwestią pozostaje pytanie, czy jej determinacja nie osłabnie pod wpływem działań Kremla?

W wypadku Rosji pytania brzmią następująco - po pierwsze: dlaczego Kreml podejmuje działania w sprawie zmiany status quo w stosunkach z Białorusią, po drugie: czy Rosja jest zdeterminowana w swych działaniach, i po trzecie: jakich narzędzi używa w tym celu? Wybór określonych narzędzi stosowanych przez Rosję jest probierzem rzeczywistych intencji i determinacji w zakresie budowy nowego modelu relacji z Białorusią, w tym także gotowości do jej połączenia się w ramach pogłębionej integracji.

W pierwszej części niniejszego artykułu zostaną przeanalizowane okoliczności dotyczące podjęcia przez Rosję wysiłków na rzecz zdynamizowania procesu integracji rosyjsko-białoruskiej w ramach koncepcji pogłębionej integracji. W drugiej części - porównywane są działania strony rosyjskiej i białoruskiej w odniesieniu do obecnej odsłony działań scalających, ze szczególnym uwzględnieniem stosowanych strategii i kontrolowanych zasobów, które wykorzystują Rosja i Białoruś. W części trzeciej podjęto próbę skonstruowania idealnych scenariuszy dotyczących przyszłości stosunków rosyjsko-białoruskich z uwzględnieniem osi continuum determinacji zmiany/utrzymania obecnego modelu stosunków dwustronnych. W konkluzjach zostanie wskazane, który ze scenariuszy ewolucji polityki Rosji wobec Białorusi jest najbardziej prawdopodobny.

\section{Nowy etap rozwoju stosunków rosyjsko-białoruskich: w stronę pogłębionej integracji}

Jako pretekstu, który miałby skłonić Białoruś do podjęcia wysiłków w sprawie faktycznego zbliżenia obydwu państw, strona rosyjska użyła argumentu finansowego wynikającego $\mathrm{z}$ drugiego etapu tzw. manewru podatkowego.

7 Tamże, s. 55-56. 
Polegał on na zastąpieniu ceł eksportowych za wywóz ropy naftowej i wyrobów ropopochodnych za granicę tzw. podatkiem od kopalin. Wprowadzenie w życie tych rozwiązań oznaczało istotne straty dla białoruskiego budżetu czerpiącego znaczne dochody $\mathrm{z}$ ceł eksportowych wspomnianych produktów ${ }^{8}$. W tej m.in. sprawie 13 XII 2018 r. w Brześciu odbyło się spotkanie Dmitrija Miedwiediewa i Siarhieja Rumasa, premierów Rosji i Białorusi, które w znacznej mierze poświęcono kwestii cen gazu dla Białorusi, wzajemnego uznawania wiz i rekompensowania Białorusi strat wynikających z owego manewru podatkowego ${ }^{9}$. W trakcie rozmów Miedwiediew zaproponował dwa scenariusze dalszej współpracy dla obu państw z uwzględnieniem porozumienia z 1999 r. - konserwatywny i zaawansowany. Pierwszy, określany przez Miedwiediewa mianem konserwatywnego, zakładał dalsze wypełnianie treścią wspomnianego porozumienia, ale bez powoływania do życia wszystkich instytucji, które ono przewidywało. Temu wariantowi miałaby towarzyszyć intensyfikacja prac na rzecz Eurazjatyckiej Unii Gospodarczej. Wariant drugi, zaawansowany, miałby na celu zwiększenie stopnia integracji obu państw do poziomu instytucjonalizacji przewidzianego w umowie z 1999 r., przy jednoczesnym integrowaniu gospodarek obu państw ${ }^{10}$.

Koncepcja pogłębionej integracji, która wybrzmiała z ust Miedwiediewa, była $\mathrm{w}$ istocie próbą wypełnienia stosunków rosyjsko-białoruskich treściami wynikającymi z Umowy o utworzeniu Państwa Zwiazkowego. Informacje

8 Koszty dla białoruskiego budżetu miały w 2019 r. wynieść 300 tysięcy dolarów, a za sześć lat nawet 2 miliardy dolarów. Zmiany te (wprowadzane przez Rosję od 2015 r. w ramach pierwszego etapu tzw. manewru podatkowego) dotknęłyby najpierw boleśnie białoruskie rafinerie, które w przeciwieństwie do rosyjskich nie zostały objęte mechanizmem kompensacji wzrostu cen ropy. Zob. Białoruś czekaja trudne rozmowy na temat cen ropy naftowej, Belsat.TV [online], 10 VIII 2018 [dostęp: 31 I 2020], dostępny w internecie: <https:// belsat.eu/p1/news/bialorus-czekaja-ciezkie-rozmowy-na-temat-cen-ropy-naftowej/>.

9 Rumas i Medvedev progulâlis ' po Brestskoj kreposti, no po nefti i vizam ne dogovorilis', TUT.BY [online], 13 XII 2018 [dostęp: 24 XI 2019], dostępny w internecie: <https:// news.tut.by /economics/619111.html>.

10 Wydarzenie z 11 XI 2018 rzuca dodatkowe światło na dotychczasowe dyskusje toczące się między Mińskiem a Moskwą wokół rozliczeń finansowych. Rosyjski wicepremier odpowiedzialny za sektor paliwowo-energetyczny Rosji, Dmitrij Kozak, postawił wówczas ultimatum białoruskiemu wicepremierowi Igorowi Laszenko, zgodnie z którym nie będzie żadnych dyskusji na temat ulg i kompensacji manewru podatkowego do chwili podjęcia zasadniczych decyzji w zakresie dalszej integracji Rosji i Białorusi w ramach Państwa Związkowego. Zob. Konservativnyj i prodvinutyj. Medvedev rasskazal o dvuh scenariâh integracii s Belarus' $\hat{u}$, TUT.BY [online], 13 XII 2018 [dostęp: 24 XI 2019], dostępny w internecie: <https://news.tut.by /economics/619120.html>; Kozak ne stal obsuždat's belorusskoj delegaciej skidku na gaz, Interfaks [online], 11 XII 2018 [dostęp: 24 XI 2019], dostępny w internecie: <https://www.interfax.ru/russia/641836>. 
na temat przedmiotu negocjacji oraz ich postępów z wielkim trudem przenikały do opinii publicznej obu państw, a przecieki, o których więcej poniżej, wywoływały podejrzliwość, a także zarzuty, że są ewidentnym fałszerstwem.

We wrześniu 2019 r. w rosyjskim „Kommiersancie” pojawił się obszerny artykuł ujawniający zarys koncepcji pogłębionej integracji, tj. treść dokumentu znanego pod nazwą Program działań Białorusi i Rosji ws. realizacji założeń „Umowy o utworzeniu Państwa Zwiazkowego”, który 6 września parafowali premierzy obu państw. Dokument przewidywał daleko idącą integrację gospodarczą Rosji i Białorusi. Trudno byłoby uznać ją za integrację równoprawnych podmiotów, biorąc pod uwagę blisko trzydziestokrotną różnicę wielkości gospodarek obu państw - w 2018 r. PKB Białorusi stanowiło 3,4 proc. PKB Rosji. Propozycje w nim zawarte wykraczały poza rozwiązania stosowane w Unii Europejskiej, a w niektórych przypadkach przypominały model wykorzystywany w konfederacji czy wręcz w federacjach ${ }^{11}$. Zakładano m.in. ustanowienie jednego systemu podatkowego - do 1 kwietnia 2021 r. miałby zostać przyjęty wspólny Kodeks podatkowy. Uwspólnotowieniu miały ulec również od 2021 r. polityka celna (łącznie z infrastrukturą i służbą) oraz polityka energetyczna. W dokumencie wprost używane jest sformułowanie: „ustanowienie jednolitego regulatora rynków gazu, ropy, wyrobów ropopochodnych i energii elektrycznej"' ${ }^{12}$. Strony podjęły także zobowiązania w zakresie unifikacji kodeksów cywilnych, realizacji wspólnej polityki pracy i polityki społecznej. Z dyskusji nad pogłębioną integracją, co wynikało z treści Programu działań, wyłączone zostały kwestie obronności, bezpieczeństwa narodowego, sądownictwa, a także ustroju politycznego Państwa Związkowego ${ }^{13}$.

W grudniu delegacje obu państw musiały spotkać się dwukrotnie. Celem było podpisanie tzw. map drogowych dotyczących dalszej integracji. Na drodze tym wysiłkom - osiągnięciu wiążących decyzji, np. co do zasad zmiany trybu podejmowania decyzji w państwie związkowym - stanęły kwestie dostaw surowców naturalnych, kompensacji manewru podatkowego i dostępu do rynku towarów rosyjskich i białoruskich ${ }^{14}$.

11 D. Butrin, Družba nalogov. Rossiâ i Belorussiâ namereny v 2021 godu perejti na edinyj Nalogovyj kodeks i ne tol'ko, „Kommersant"”, 16 IX 2019, nr 167, s. 1.

12 Tamże.

13 Tamże.

14 A. Klaskovskij, Lukašenko i Putin vrâd li vyp'ût samogonki pered Novym godom. Kreml'

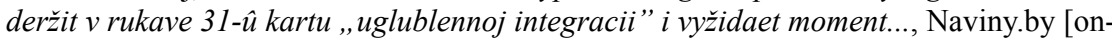
line], 26 XII 2019 [dostęp: 21 I 2020], dostępny w internecie: <https://naviny.by/article /20191226/1577363713-lukashenko-i-putin-vryad-li-vypyut-samogonki-pered-novym-godom>. 
W świetle poczynionych $\mathrm{w}$ toku grudniowej rundy negocjacyjnej ustaleń, można uznać, że kluczowe kwestie dotyczące pogłębionej integracji i bieżących stosunków gospodarczych będą się wzajemnie przeplatały, a ich rozwiązanie nastąpi dopiero w ciągu nadchodzących kilku lat. W 2020 r. ma mieć miejsce rewizja ustawodawstwa celnego obu państw, co otworzy drogę harmonizacji obu systemów; analogiczne sprawy odnośnie do ustawodawstwa podatkowego (przyjęcie wspólnego Kodeksu Podatkowego) potrwają jeszcze dłużej i dopiero w 2022 r. Białoruś mogłaby liczyć na kompensację poniesionych strat przez jej sektor przetwórstwa ropy naftowej ${ }^{15}$. Jeśli więc prawdą jest informacja o istnieniu 31. mapy drogowej dotyczącej wspólnej waluty i wspólnego centrum emisji pieniądza oraz ponadnarodowych organów władzy państwowej, to prace na tym odcinku realnie rozpoczęłyby się w $2023 \mathrm{r}$.

Tymczasem rok 2020 zastał oba państwa bez wiążących umów w sprawie cen gazu i ropy (w przypadku gazu podpisano umowę do końca lutego 2020 r.). Ropa miała być dostarczana nawet w obliczu braku umowy, którą obie strony będą negocjować z uwzględnieniem wzrostu podatku od wydobycia surowca ${ }^{16}$. Na początku stycznia jej dostawy zostały jednak wstrzymane ${ }^{17}$.

15 Û. Carik, Sočinskij sammit: Lukašenko i Putin ostaûtsâ „pri svoem”, Riddle [online], 16 XII 2019 [dostęp: 31 I 2020], dostępny w internecie: <https://www.ridl.io/ru/ sochinskij-sammit-lukashenko-i-putin-ostajutsja-pri-svoem/>.

16 Eukaszenka kazat kupować rope spoza Rosji, Belsat.eu [online], 1 I 2020 [dostęp: 31 I 2020], dostępny w internecie: <https://belsat.eu/pl/news/lukaszenka-kazal-kupowac-rope-spoza-rosji/>; Rosyjski gaz dla Białorusi zagwarantowany do marca, Belsat.eu [online], 1 I 2020 [dostęp: 31 I 2020], dostępny w internecie: <https://belsat.eu/pl/news/ rosyjski-gaz-dla-bialorusi-zagwarantowany-do-marca/?fbclid=IwAR2bezHd7CwC-8KI XPO70YqJzuthsMRlgxZonKqQgX1LmcW6j83MIcKCXJQ>.

17 Kreml oczekuje, żeby Białoruś wróciła do stołu negocjacyjnego i kontynuowała pracę nad mapami drogowymi. Rosyjskie firmy odmówiły udzielenia w 2020 r. Białorusi zniżki mającej zrekompensować skutki manewru podatkowego. Zmniejszenie cła eksportowego na ropę w Rosji prowadzi do tego, że jej wartość dla Białorusi, która otrzymuje ją wolną od cła, rośnie. Wzrost cen wyniósł 5 proc. W 2020 r. białoruskie zakłady przetwórstwa ropy mogły stracić według różnych szacunków od 320 do 360 milionów dolarów. Białoruś w odpowiedzi wprowadziła dodatkowe opłaty za tranzyt ropy przez jej terytorium; aby „wyjść na swoje” Mińsk musiałby jednak je podnieść aż o 70 proc. Kreml jest zdeterminowany w swych działaniach, lecz nie zamierza doprowadzić Białorusi na skraj przepaści. Wewnętrzne białoruskie zapotrzebowanie na ropę jest zaspokajane przez firmy Michaiła Gucerijewa, blisko współpracującego z Łukaszenką, który ,zaangażowany jest w znaczące przedsięwzięcie biznesowe na Białorusi, finansowane z chińskiego kredytu, w związku z tym, nawet bez 5 proc. premii, wychodzi na swoje, współpracując z Łukaszenką". Û. Carik, Družba bez nefti, Riddle [online], 23 I 2020 [dostęp: 31 I 2020], dostępny w internecie: $<\mathrm{https}$ ://www.ridl.io/ru/druzhba-bez-nefti/>; D. Kozlov, Uporstvo, dostojnoe neftânogo primeneniâ, „Kommersant"”, 14 I 2020, s. 7; Struktury Mihaila Gucerieva načali postavki nefti v Belorussiû, Interfax [online], 14 I 2020 [dostęp: 31 I 2020], dostępny w internecie: $<$ https://www.interfax.ru/business/691170>. 
Ówczesny kryzys energetyczny uznawano za wyjątkowy w historii stosunków rosyjsko-białoruskich. Po raz pierwszy to Białoruś odstąpiła od dalszych negocjacji na wniosek Łukaszenki, który nakazał kierownictwu kompleksu paliwowo-energetycznemu zakup ropy z alternatywnych źródeł ${ }^{18}$.

Proces negocjacyjny w 2019 r. w sprawie pogłębionej integracji uległ ,rozmiękczeniu" przez kwestie dodatkowe, tj. rekompensatę za zanieczyszczoną ropę, zmianę zasad podejmowania decyzji o blokowaniu dostępu białoruskich towarów do rosyjskiego rynku, a także „rozciągnięciu” w czasie. Świadczyło to o braku determinacji ze strony Rosji do zmiany istniejącego modelu relacji z Białorusią, nie mówiąc już o jej statusie prawno-międzynarodowym. Wstrzymywanie dostaw surowców energetycznych na Białoruś nie było niczym nowym w arsenale środków rosyjskiej dyplomacji. Problemy zaś, które u progu 2020 r. po raz kolejny napotkała Białoruś w zakresie ustalenia korzystnych dla niej cen ropy, dowodziły, że Mińsk jeszcze nie poddał się dyktatowi Rosji w obszarze integracyjnym. W drugiej połowie lutego 2020 r., tuż po wizycie Igora Sieczina w Mińsku, strona rosyjska wyraziła gotowość zrekompensowania Białorusi strat, jakie wyniknęły z tzw. manewru podatkowego ${ }^{19}$.

\section{Przesłanki zmiany podejścia Rosji do Białorusi}

Za nowe otwarcie w procesie kształtowania się stosunków rosyjsko-białoruskich odpowiadała strona rosyjska. Zmianę stosunku Federacji Rosyjskiej do Białorusi wiąże się z szerszym problemem, czyli z przewartościowaniem podejścia Kremla do środowiska międzynarodowego i aktywnością na obszarze poradzieckim, który zapoczątkowany został jeszcze w 2008 r. Przełom lat 2018 i 2019, gdy strona rosyjska zaproponowała intensyfikację procesu integracji obu państw, stał się momentem kulminacyjnym w długoletniej rewizji modelu współpracy rosyjsko-białoruskiej, a w przypadku Białorusi rozpoczął się jeszcze w 2015 r. Obejmował on m.in.:

- ograniczanie poziomu subsydiowania białoruskiej gospodarki (tzw. renty integracyjnej) polegające na zmniejszeniu poziomu dostaw ropy naftowej

18 Û. Carik, Družba bez nefti...

19 A. Toporkov, E. Vavina, S. Bočarova, Rossiâ soglasna na ustupki Belorussii v postavkah nefti. Kompensirovat' ee poteri ot nalogovogo manevra predloženo rossijskim neftânikam, Vedomosti [online], 21 II 2020 [dostęp: 8 III 2020], dostępny w internecie: $<$ https://www.vedomosti.ru/business/articles/2020/02/21/823623-rossiya-soglasna-na-ustupki-v-postavkah-nefti?utm_source=facebook.com\&utm_medium=social\&utm campaign=rossiya-gotova-kompensirovat-belorussii\&fbclid=IwAR1tvC9zb4V7O2fzh VO-CouULeuITrmJ4D4yWE6xK01QNO1fUzK-1ZAy7EE>. 
i zainicjowaniu procedury manewru podatkowego, podniesieniu cen importu gazu i ropy, wprowadzeniu dodatkowych ograniczeń w dostępie białoruskich produktów na rosyjski rynek ${ }^{20}$;

- działania na rzecz uporządkowania zasad obrotu wyrobami ropopochodnymi i ograniczenia w omijaniu przez Białoruś obowiązujących antyzachodnich kontrsankcji wprowadzonych przez Rosję po 2014 r.;

- rosnącą presję ze strony Rosji w kwestii integracji wojskowej, w tym także próbę jednostronnej decyzji o ustanowieniu na Białorusi rosyjskiej bazy wojskowej i rozpoczęcie rozmieszczania w 2016 r. w regionach graniczących z Białorusią (briańskim i smoleńskim) brygad strzelców zmotoryzowanych; rozbudowa tych baz była kontynuowana w następnych latach ${ }^{21}$.

Celem tych działań miało być ograniczenie swobody Białorusi na arenie międzynarodowej, zmniejszenie kosztów ponoszonych przez stronę rosyjską na rzecz stabilizowania reżimu Łukaszenki i trwałe podporządkowanie interesom Rosji. Skutkować to mogło naruszeniem białoruskiej suwerenności, a w dalszej perspektywie zlikwidowaniem jej niepodległości ${ }^{22}$. Za przyczynę takiego stanu rzeczy uważa się rozdrażnienie Kremla niechęcią Białorusi do wspólnego zaangażowania w konfrontację z Ukrainą oraz z Zachodem, wysiłki Mińska dotyczące pokojowego uregulowania konfliktu i próby uzyskania samodzielnej tożsamości międzynarodowej. Poskutkowało to ,pogłębieniem się [w Rosji M.S.] fobii związanej z utratą geopolitycznej kontroli nad Białorusią i pociągnęło za sobą stan permanentnego napięcia w stosunkach dwustronnych"”23.

Kreml coraz wyraźniej artykułował również swą niechęć w stosunku do międzynarodowych „manewrów” Białorusi i jej zabiegów na rzecz zachowania prawa do suwerennych decyzji w sferze polityki zagranicznej. Zbliżenie z Zachodem nie pozostawało niezauważone w Rosji. Wzbudziło niezadowolenie

20 Niektóre szacunki wskazują, że w ciągu ostatnich trzech lat, w wyniku zmian w odniesieniu do ukrytych schematów subsydiowania dostaw ropy i gazu ze strony Rosji, Białoruś straciła znaczną część swego produktu krajowego brutto: „w najlepszym okresie zarabiała do 12 proc. PKB na surowcach energetycznych [...] średni poziom tych wpływów zmniejszył się do poziomu 3-5 proc. PKB”. Zob. Â. Romančuk, Beg na meste-obŝeprimirâûse. Âroslav Romančuk o tom, počemu anšlûs Belarusi ne sostoitsâ, The Insider [online], 8 XII 2019 [dostęp: 21 I 2020], dostępny w internecie: <https://theins.ru/opinions/191709>.

21 A. Sivitsky, Belarus-Russia. From a strategic deal to an integration ultimatum, "Russia Foreign Policy Papers" [online], 16 XII 2019 [dostęp: 21 I 2020], dostępny w internecie: <https://www.fpri.org/article/2019/12/belarus-russia-from-a-strategic-deal-to-anintegration-ultimatum/>; Y. Tsarik, L. Vasa, Foreign policy challenges for Belarus since 2014 and their domestic dimension, KKI Policy Brief, E-2019/33, Institute for Foreign Affairs and Trade, Budapeszt 2019, s. 5-6.

22 A. Sivitsky, Belarus-Russia...

23 Tamże. 
i oskarżenia o sprzyjanie interesom Stanów Zjednoczonych i Polski, w szczególności w tzw. patriotycznych kręgach ${ }^{24}$. Niezadowolenie w Moskwie wywołała odbudowa stosunków ze Stanami Zjednoczonymi, a zwłaszcza spotkanie w sierpniu 2019 r. w Warszawie prezydenckich doradców ds. bezpieczeństwa narodowego Stanów Zjednoczonych, Polski, Ukrainy i Białorusi oraz próba instytucjonalizacji mechanizmu czterostronnych konsultacji, czyli „quadu”25. Jednak już wcześniej przedstawiciele rosyjskich służb wywiadowczych wyrażali zaniepokojenie białoruskim zwrotem w stronę Zachodu i rozchodzeniem się interpretacji źródeł zagrożenia dla bezpieczeństwa narodowego Państwa Związkowego ${ }^{26}$. Strona rosyjska nie była usatysfakcjonowana istniejącym poziomem współpracy w dziedzinie obronności i zaczęła naciskać na instalację własnej bazy wojskowej na terytorium Białorusi ${ }^{27}$. Brak zgody ze strony Mińska na propozycje Rosji przyczynił się m.in. do rozmieszczenia rosyjskich wojsk na granicy z Białorusią i zamknięcia granicy rosyjsko-białoruskiej dla obywateli państw trzecich ${ }^{28}$.

Rosyjski manewr podatkowy stawiał przed Białorusią poważne wyzwanie w zakresie konieczności zaakceptowania kremlowskiego dictum w obszarze unifikacji ustawodawstwa podatkowego. Zdaniem części obserwatorów oznaczałoby to znaczne straty dla Łukaszenki i związanych z nim białoruskich przedsiębiorców, a zarazem tłumaczyło opór Mińska w odniesieniu do idei pogłębionej integracji $\mathrm{i}^{29}$.

24 G. Ioffe, At second Minsk dialogue forum, Belarus seeks to redefine its reputation, "Eurasia Daily Monitor", vol. 16, No. 145 [online], 21 X 2019 [dostęp: 31 I 2020], dostępny w internecie: $<$ https://jamestown.org/program/at-second-minsk-dialogue-forum-belarusseeks-to-redefine-its-reputation/>; A. Klaskovskij, Vojny čužie i svoi. Medvedev brosil kamen'v ogorod Lukašenko i polučil otvetku, Naviny.by [online], 5 XI 2019 [dostęp: 31 I 2020], dostępny w internecie: <https://naviny.by/article/20191105/1572932516-voyny-chuzhie-i-svoi-medvedev-brosil-kamen-v-ogorod-lukashenko-i $>$.

25 A. Grâzev, Vostočnoe pritvorstvo. Počemu Belorussiâ ne spešit ukreplât' soûz s Rossiej, no gotova družit's SŠA i Pol'šej?, Lenta.ru [online], 29 X 2019 [dostęp: 31 I 2020], dostępny w internecie: $<$ https://lenta.ru/articles/2019/10/24/great poland/?mc cid=8e $80 \mathrm{c}-$ 19b34\&mc_eid=4b516b0c01\&fbclid=IwAR2Ze_jdGzvvJHlp-Fg4REdxy6c_vqNuRdJdznSFiENuIyVXEZT3j8jooZk>.

26 A. Sivitsky, Belarus-Russia...

27 Jednocześnie zdecydowanie przeciwstawiał się od 2016 r. utworzeniu na terytorium Białorusi rosyjskiej bazy wojskowej (w Bobrujsku) i rozmieszczeniu w niej pułku lotnictwa składającego się z 24 myśliwców Su-27 SM3 i 4 śmigłowców Mi-8.

28 Y. Tsarik, Belarus and Russia. On the evolution of a ,hybrid union”, Riddle [online], 19 XI 2018 [dostęp: 31 I 2020], dostępny w internecie: <https://www.ridl.io/en/ belarus-and-russia-on-the-evolution-of-a-hybrid-union/>.

29 J. Cialpuk, Przyczyna zjednoczeniowego impasu: rodzina Lukaszenki traci na integracji z Rosją?, Belsat.eu [online], 4 X 2020 [dostęp: 31 I 2020], dostępny w internecie: <https://belsat.eu/pl/news/glowna-przyczyna-zjednoczeniowego-impasu-rodzinalukaszenki-traci-na-integracji-z-rosja/>. 
Kreml sięgnął jednak po jeszcze jeden mechanizm oddziaływania na Białoruś - całkiem nowy w relacjach dwustronnych. Mowa tu o powołaniu Michaiła Babicza na stanowisko ambasadora Rosji na Białorusi. Jego nagłe powołanie i równie szybkie odwołanie (nie piastował tego stanowisku nawet rok, choć jego poprzednik urzędował tam 12 lat, bo od 2006 r.), także status, jaki został mu udzielony (łączył funkcję $\mathrm{z}$ tytułem pełnomocnego przedstawiciela Prezydenta FR ds. rozwoju współpracy gospodarczo-handlowej z Białorusią), a przede wszystkim styl sprawowania urzędu - uznaje się za probierz stanu relacji rosyjsko-białoruskich oraz oczekiwań strony rosyjskiej w stosunku do tempa i charakteru dalszej współpracy obu państw. Celem Babicza było dokonanie audytu tych stosunków, tj. zebranie informacji na temat ich faktycznego stanu w wymiarze finansowym, sposobu wykorzystania środków finansowych płynących z Rosji na Białoruś, przestrzegania przez Białoruś zasad embarga na produkty europejskie, a następnie wykorzystanie ich $\mathrm{w}$ celu prowokacji Łukaszenki oraz osób z jego najbliższego otoczenia, którzy czerpali zyski z braku przejrzystości zasad rozliczeń rosyjsko-białoruskich $^{30}$. Babicz zaangażował się jednak w bieżącą białoruską politykę w stopniu wykraczającym poza standardy przyjęte w relacjach rosyjsko-białoruskich. Odwiedzał zakłady pracy, spotykał się z przedstawicielami organizacji społecznych i opozycyjnych sił politycznych. Brał udział w dyskusjach na temat bieżących problemów społeczno-politycznych i gospodarczych Białorusi, naruszając monopol Łukaszenki, niekiedy otwarcie wchodząc z nim w polemi$k_{e ̨}^{31}$. Jego odwołanie mogło oznaczać, że Mińsk zdecyduje się współpracować z Moskwą w dziele budowy Państwa Związkowego; jego pozostanie zaś na placówce groziło dalszą destabilizacją systemu politycznego w stopniu niemożliwym do sprowokowania przez żadnego z zachodnich dyplomatów, a który dla Łukaszenki zaczynał być niepokojący ${ }^{32}$. Już w 2007 r. pojawiły się w literaturze przedmiotu opinie, że „,dotychczasowa formuła pozornego zbliżenia w ramach Państwa Związkowego wyczerpała się” i „Rosja przestała być

30 Posol Babič: nikto nikogda ne predlagal Belarusi vstupit'v sostav Rossii, Naviny.by [online], 14 III 2019 [dostęp: 31 I 2020], dostępny w internecie: <https://naviny.by/article /20190314/1552570803-posol-babich-nikto-nikogda-ne-predlagal-belarusi-vstupit-v-sostav-rossii>; Posol Rossii prokommentiroval slova Lukašenko o real'noj stoimosti Belaès, TASS [online], 19 IV 2019 [dostęp: 31 I 2020], dostępny w internecie: <https://tass.ru/ ekonomika/6354766>.

31 V. Solov'ev, Krymskâ̂ vesna teper' $i$ v Minske, „Kommersant"”, 19 III 2019, s. 6.

32 S. Bočarova, E. Muhametšina, Začem Putin smenil posla v Belorussii, „Vedomosti”, 1 V 2019; MID Belorussii obvinil rossijskogo posla v popytke razrušit'otnošeniâ Moskvy i Minska, TASS [online], 19 IV 2019 [dostęp: 31 I 2020], dostępny w internecie: <https:// tass.ru/mezhdunarodnaya-panorama/6355862>. 
czynnikiem stabilizacji sytuacji na Białorusi i źródłem wsparcia prezydentury Łukaszenki, a stała się głównym zagrożeniem trwałości jego rządów"33. Co więcej, Rosja swym podejściem do Białorusi „wymusi na władzach białoruskich działania mające na celu umocnienie poparcia własnego społeczeństwa [...], a ich elementem będzie zapewne nasilenie retoryki niepodległościowej i obarczenie strony rosyjskiej odpowiedzialnością za trwały, strukturalny kryzys we wzajemnych relacjach" ${ }^{34}$.

Te prognozy spełniły się w dużej mierze. Przed 2019 r. na Kremlu nie wypracowano jednak spójnej strategii dotyczącej demontażu reżimu Łukaszenki. Nie sposób oprzeć się wrażeniu, że sam Łukaszenka jest zainteresowany tym, by budować wrażenie nieuniknionej aneksji Białorusi i jego rychłego obalenia przez Kreml. Poza tym pozycjonowanie się w charakterze jedynego obrońcy białoruskiej niepodległości sprzyja również jego strategii legitymizacji władzy. Warto mimo wszystko odnotować obecność w rosyjskim dyskursie publicznym scenariuszy, które przewidywały konieczność zastąpienia Łukaszenki innym politykiem, w przeciwnym przypadku Rosja ,straci” Białoruś, tak jak stało się to z Ukrainą. Mowa tu o prognozie przygotowanej w odniesieniu do Białorusi przez Moskiewski Państwowy Instytut Stosunków Międzynarodowych Ministerstwa Spraw Zagranicznych Rosji (MGIMO) z 2018 r., w myśl której Łukaszenka będzie się bronił wszelkimi sposobami przed dalszą integracją z Rosją ${ }^{35}$. A ,im dłużej Łukaszenka będzie pozostawał u władzy, tym większe jest prawdopodobieństwo rozwoju najgorszego dla Rosji scenariusza"36.W związku z tym „Kreml musi doprowadzić jak najszybciej do przekazania władzy na Białorusi kandydatowi prorosyjskiemu. Realnie rzecz ujmując, faktyczny proces integracji obu państw mógłby doczekać się realizacji dopiero w 2050 r." ${ }^{37}$.

\section{Wewnątrzrosyjskie uwarunkowania zmiany istniejącego modelu relacji z Białorusią}

W ciągu ostatnich kilkunastu lat Rosja coraz bardziej podporządkowywała sobie Białoruś. Osiągnęła w tym czasie wiele spektakularnych sukcesów,

33 A. Eberhardt, Gra pozorów. Stosunki rosyjsko-białoruskie 1991-2008, PISM, Warszawa 2008, s. 230-231.

34 Tamże, s. 231.

35 Mir v XXI veke: prognoz razvitiâ meždunarodnoj obstanovki po stranam i regionam: monografiâ, red. M.V. Aleksandrova, O.E. Rodionova, MGIMO-Universitet, Moskva 2018, s. 257.

36 Tamże, s. 258.

37 Tamże. 
przejmując m.in. kontrolę nad Biełtransgazem, czy wymuszając na niej członkostwo w Eurazjatyckiej Unii Gospodarczej. Jednak nie uczyniło to z Białorusi bezwolnego satelity Rosji, która wciąż poszukuje dodatkowych mechanizmów jej subordynowania, czego ostatnim przykładem jest wstrzymanie na początku 2020 r. dostaw ropy. Moskwa jednocześnie udzielała Mińskowi dodatkowych kredytów, m.in. na budowę elektrowni atomowej w Ostrowcu, czy też restrukturyzowała stare długi. Ceny na rosyjską ropę i gaz wielokrotnie ulegały w przeszłości negocjacjom i korzystnym dla Białorusi zmianom; zdarzały się również przypadki wstrzymania ich dostaw, ale strony zawsze znajdowały kompromisowe rozwiązanie ${ }^{38}$.

W związku z tym, zaczęły pojawiać się opinie, że rzeczywistym celem reaktywacji idei budowy Państwa Związkowego było wyłącznie wymuszenie na Białorusi sprzedaży rosyjskim przedsiębiorstwom dwóch rafinerii w Połocku i Mozyrzu, co jednocześnie wzmocniłoby ekonomiczny wpływ Kremla na Białoruś. Rosja miała za pośrednictwem manewru podatkowego wymusić na Mińsku sprzedaż rafinerii w Mozyrzu i Nowopołocku, których wartość oceniono na „nie mniej niż 10 mld dolarów, czyli mniej więcej tyle, ile Mińsk chciałby otrzymać od Moskwy w ramach rekompensaty za przeprowadzenie manewru podatkowego" 39 . Ta kwestia pojawiła się w dywagacjach na temat zaangażowania Sieczina w sprawę uregulowania konfliktu wokół dostaw rosyjskiej ropy na Białoruś (Rosnieft' zaspokaja niemal połowę zapotrzebowania Białorusi na ten surowiec). Sugerowano, że Sieczyn w zamian za zmianę stanowiska Kremla wobec rekompensaty strat dla Białorusi, wynikających z manewru podatkowego, uzyska kontrolny pakiet akcji w rafinerii w Mozyrzu i/lub udział w nowopołockim Naftanie, a także zgodę Łukaszenki „na lobbowanie liberalizacji zasad eksportu gazu ziemnego transportowanego gazociągiem, korzystnych dla Rosnieftu"40.

38 M. Samorukov, Pogloŝenie, kotorogo net. Počemu Kreml' ne možet vybit' ustupki iz Lukašenko, Moskovskij Centr Karnegi [online], 9 XII 2019 [dostęp: 31 I 2020], dostępny w internecie: <https://carnegieendowment.org/publications/80528>.

39 Białoruś sprzeda Rosji rafinerię? Kreml ma wiele do zyskania, Polskie Radio24.pl [online], 8 I 2019 [dostęp: 31 I 2020], dostępny w internecie: <https://polskieradio24.pl/75/921/ Artykul/2242613,Bialorus-sprzeda-Rosji-rafinerie-Kreml-ma-wiele-do-zyskania> .

40 A. Toporkov, E. Vavina, S. Bočarova, Rossiâ soglasna na ustupki Belorussii... Więcej na ten temat zob: S. Kardaś, K. Kłysiński, Rosyjsko-białoruski spór naftowy: taktyczne ustępstwa Kremla, Ośrodek Studiów Wschodnich (Analizy), 26 II 2020, dostępny w internecie [dostęp: 8 II 2020]: <https://www.osw.waw.pl/pl/publikacje/analizy/2020-02-26/ rosyjsko-bialoruski-spor-naftowy-taktyczne-ustepstwa-kremla?fbclid=IwAR20WUpN5nNO7iTmv-Pi7LuvmMNuoRObiZ2s-vMcH34uTGi07gNg7iCAzE >. 
Destabilizacja sytuacji społeczno-gospodarczej Białorusi, sprowokowana manewrem podatkowym, i desperackie próby uzyskania dodatkowych źródeł dochodu dla budżetu wpłynęłyby także na rewizję negatywnego dotychczas stanowiska Łukaszenki wobec wyprzedaży rosyjskim oligarchom dochodowych przedsiębiorstw spoza sektora paliwowo-energetycznego. Znacząca grupa państwowych białoruskich przedsiębiorstw sektora bankowego, ubezpieczeniowego, usług pocztowych, metalurgii i przetwórstwa drewna broniona była przez białoruskiego prezydenta zarówno przed rosyjskim biznesem, jak i prywatyzacją, a on sam w związku z tym stał się obiektem ataków medialnych i elektronicznych ze strony rosyjskiej ${ }^{41}$.

Nie ma wątpliwości, że kremlowski obóz władzy nieustannie poszukuje dodatkowych, w tym także zewnętrznych (geopolitycznych), źródeł legitymacji reżimu politycznego. W myśl tej narracji integracja z Białorusią bez konieczności uciekania się do użycia siły militarnej, zostałaby pozytywnie odebrana przez rosyjskie społeczeństwo. Powołanie do życia ponadnarodowych organów władzy państwowej na potrzeby Państwa Związkowego pozwoliłoby także - hipotetycznie - zachować Władimirowi Putinowi możliwość kontroli nad rosyjską polityką po 2024 r., gdyby zdecydował się objąć stanowisko Przewodniczącego Rady Najwyższej Państwa Związkowego. Założenie to wywołuje jednak sporo wątpliwości, biorąc pod uwagę, jak długa i skomplikowana droga wiedzie do przyjęcia wciąż niepodpisanego Aktu Konstytucyjnego Państwa Zwiazkowego, a także jaki jest faktyczny stosunek Rosjan do idei budowy wspólnego z Białorusią państwa ${ }^{42}$.

W świetle przeprowadzonych w kwietniu 2019 r. badań przez rosyjski WCIOM stawało się oczywiste, że społeczeństwo rosyjskie nie jest gotowe do integracji z Białorusią. Przede wszystkim trzeba odnotować, że 51 proc. badanych po raz pierwszy w 2019 r. dowiedziało się, że Rosja i Białoruś budują Państwo Związkowe, a 48 proc. Rosjan nie uważa integracji obu państw za konieczną, ponieważ jest zdania, że suwerenne, dobrosąsiedzkie stosunki w zupełności wystarczą. Spośród tych osób, które popierały ideę integracji,

41 L. Merežkovskij, Začem rossijskie èlity raskačivaût ,,lodku” belorusskoj stabil'nosti, Česnok [online], 11 X 2019 [dostęp: 31 I 2020], dostępny w internecie: <https://4esnok. by/mneniya/rossijskie-elity-raskachivajut-belarus/>.

42 V hode vizita $v$ Minsk prezidenta Rossii Vladimira Putina budet podpisan konstitucionnyj akt, kotoryj provozglašaet soûznoe gosudarstvo Rossii i Belorussii, „Èho Moskvy” [online], 7 XII 2007 [dostęp: 31 I 2020], dostępny w internecie: <https://echo.msk.ru/ news/411401.html>; Proekt Konstitucionnogo akta Soûznogo gosudarstva, Postoânnyj Komitet Soûznogo gosudarstva [online], 14 IV 2005 [dostęp: 31 I 2020], dostępny w internecie: $<$ https://www.postkomsg.com/news/various/170103/>. 
18 proc. uważało, że powinno to być zjednoczenie dwóch równoprawnych podmiotów; 17 proc. widziało Białoruś w składzie Federacji Rosyjskiej jako jeden lub wiele podmiotów ${ }^{43}$. W przeciwieństwie do casusu Krymu, w rosyjskim społeczeństwie nie ma woli „rozbudowy potęgi Rosji kosztem Białorusi"44, a co więcej, Białoruś nie jest przedmiotem sporu z Zachodem, nie znajduje się również pod jego patronatem, nikt otwarcie nie występuje w obronie białoruskiej suwerenności. Jest to o tyle istotne, gdyż społeczna percepcja inkorporacji Krymu „skażona” była dumą z poczynań Kremla przeciwstawiającego się dominacji Zachodu i możliwości zademonstrowania mu swojej woli i potencjału ${ }^{45}$.

Równie popularna narracja głosi, że strona rosyjska nie dąży wcale do obalenia Łukaszenki, ani też zintegrowania Białorusi, jedynie nie chce „dokładać się do białoruskiego cudu gospodarczego" w stopniu przekraczającym konieczność podtrzymania stabilności sytuacji społeczno-gospodarczej ${ }^{46}$. W takich warunkach można sobie pozwolić właśnie na manewr podatkowy i twarde stanowisku w sprawie gazu. „Jeśli jednak na Białorusi pojawi się realna groźba destabilizacji, Rosja nie porzuci swojego wzorcowego sojusznika i pospieszy z pomocą z nowymi ulgami i kredytami" ${ }^{47}$.

Mińsk cieszy się pewną swobodą działania w trakcie negocjacji z Rosją (nieproporcjonalnie wysoką, biorąc różnice potencjałów gospodarczych obu państw i stopień zależności Białorusi od rosyjskich surowców energetycznych), co zdaniem niektórych komentatorów wynika przede wszystkim z braku zgody w obrębie rosyjskiej elity władzy w kwestii przyszłości Białorusi ${ }^{48}$. Napięcie w odniesieniu do białoruskiego kierunku rosyjskiej polityki zagranicznej syntetycznie streścił swego czasu Michaił Winogradow, szef Fundacji „Petersburska Polityka”: „Rosyjska elita nie pierwszy rok rozerwana jest [w odniesieniu do polityki wobec Białorusi - M. S.] między trzema tendencjami: podświadomą chęcią dokonania ekspansji terytorialnej pod pozorem «pogłębionej integracji», stosunkowo niskiej motywacji, by tego dokonać,

43 Rossiâ i Belorussiâ: novyj format integracii?, Vserossijskij centr izučeniâ obŝestvennogo mneniâ (VCIOM) [online], 2 IV 2019 [dostęp: 31 I 2020], dostępny w internecie: <https:// wciom.ru/index.php?id=236\&uid=9634>.

44 A. Levinson, Rossiâ bez Belorussii, „Vedomosti”, 20 I 2020.

45 Tamże.

46 Jak zauważał Maksim Samorukow: „Dlaczego płacić więcej, jeśli pozycja Łukaszenki jest stabilna, ryzyko jego obalenia nikłe, podobnie jak «przejście na stronę Zachodu»". Zob. M. Samorukov, Poglosenie, kotorogo net...

47 Tamże.

48 Û. Drakohrust, Moskovskâ̂ igra Vladimira Makeâ, TUT.BY [online], 1 X 2019 [dostęp: 31 I 2020], dostępny w internecie: <https://news.tut.by/economics/655613.html>. 
słabszej niż chęć Białorusi uwolnienia się z braterskich objęć, a także niepokojącego wrażenia, że koszt utrzymania Białorusi w składzie Rosji będzie większy niż w chwili obecnej" ${ }^{49}$. W literaturze przedmiotu wskazuje się na istnienie trzech głównych narracji geopolitycznych dotyczących stosunków z Białorusią: braterskiej, pasożytniczej i paternalistycznej ${ }^{50}$.

Wchłonięcie Białorusi przez Rosję będzie niewątpliwie miało dla tej ostatniej pasmo konsekwencji negatywnych - od finansowych po etnopolityczne. W przypadku pełnoprawnej integracji Rosja brałaby na siebie ciężar zaspokajania rozbudzonych materialnych oczekiwań Białorusinów, radzenie sobie z nastrojami patriotycznymi, konieczność dotowania ogromnej liczby (trwale nierentownych) przedsiębiorstw, a w przypadku niewywiązywania się z tych zobowiązań - konieczność rozładowywania napięć politycznych, etnicznych i społecznych ${ }^{51}$.

Występując w grudniu 2019 r. przed Izbą Przedstawicieli i Radą Republiki, Łukaszenka zwrócił uwagę, że w kwestii przyszłości stosunków z Białorusią w chwili obecnej naciskają na rosyjskiego prezydenta szczególnie mocno przedstawiciele antybiałoruskiego lobby $^{52}$. Do pierwszej grupy można zaliczyć przedstawicieli rosyjskiego rządu, na czele z ówczesnym premierem Dmitrijem Miedwiediewem, oraz członków „bloku ekonomicznego”, czyli ministerstwa finansów i rozwoju gospodarczego; grupę tę zasilił były rosyjski ambasador na Białorusi Michaił Babicz ${ }^{53}$. Z drugiej zaś strony silnie działa lobby probiałoruskie, dążące do utrzymania Łukaszenki u władzy, istniejącego układu stosunków rosyjsko-białoruskich i rozwiązań instytucjonalno-prawnych, których były one pochodną. Do tradycyjnych obrońców Białorusi zaliczano szefów regionów współpracujących z nią gospodarczo, indywidualnych oligarchów, jak Michaił Gucerijew i Igor Sieczin, czy członków grup siłowo-biznesowych zaangażowanych w obrót produktami białoruskiego kompleksu

49 S. Bočarova, E. Muhametšina, Začem Putin smenil posla...

50 I. Klinke, Geopolitical narratives on Belarus in contemporary Russia, "Perspectives" 2008, vol. 16, No. 1, s. 123.

51 L. Merežkovskij, Začem rossijskie èlity...

52 Lukašenko: segodnâ na Putina žestočajšee antibelorusskoe davlenie, Belta.by [online], 5 XII 2019 [dostęp: 31 I 2020], dostępny w internecie: <https://www.belta.by/president/ view/lukashenko-segodnja-na-putina-zhestochajshee-anitbelorusskoe-davlenie-3717962019/?utm_source=belta\&utm_medium=news\&utm_campaign=accent $>$.

53 Podkreśla się także, że szczególnie złe nastawienie do Białorusi żywią przedstawiciele rosyjskiego sektora przetwórstwa mleka i przemysłu maszynowego, gdyż nie mogą konkurować cenowo na własnym rynku z produkcją białoruską. Nie mogą też dotrzeć na białoruski rynek z własną produkcją z powodu tamtejszego celowo zaporowego, protekcjonistycznego systemu regulacji, który bez decyzji politycznej nie zezwala na pojawienie się produkcji zagranicznej. Â. Romančuk, Beg na meste... 
przetwórstwa ropy naftowej. Proceder współpracy rosyjskich firm naftowych i reżimu Łukaszenki, polegający na unikaniu płacenia podatków rosyjskiemu budżetowi, ukształtował się w latach 1999-2007, kiedy zasady celno-podatkowe dynamizowały rosyjskich przedsiębiorców do eksportu swoich surowców z terytorium Białorusi ${ }^{54}$.

Szara strefa w obrocie ropą i wyrobami ropopochodnymi z udziałem Białorusi była intratnym procederem i w związku z tym przedmiotem zainteresowania wielu rosyjskich grup oligarchicznych i struktur przestępczych ${ }^{55}$. Ostatnio np. wzrasta znaczenie sprzedaży Ukrainie białoruskiego gazu LPG, który w rzeczywistości jest pochodzenia rosyjskiego. Rosyjskie firmy nie mogą go jednak dostarczać bezpośrednio na Ukrainę z powodu ograniczeń nałożonych przez rosyjski rząd w sprawie eksportu LPG poza obszar Eurazjatyckiej Unii Gospodarczej. Korzystają zatem z pomocy białoruskiego reżimu ${ }^{56}$.

Do grupy sympatyków status quo w relacjach rosyjsko-białoruskich zaliczyć można także rosyjskich członków rozbudowanego systemu legalizacji obłożonych kontrsankcjami zachodnich towarów wprowadzanych na rynek rosyjski z terytorium Białorusi, których symbolem jest m.in. Bremino grupp - budująca pod Orszą ogromne multimodalne przemysłowo-logistyczne centrum (Bremino-Orsha) obsługujące dostawy towarów drogą lotniczą ${ }^{57}$. Wspomniany system funkcjonował dzięki wsparciu ze strony najbliższych osób z otoczenia Łukaszenki (m.in. Wiktara Łukaszenki) ${ }^{58}$. Ten

54 M.M. Balmaceda, Energy policy in Belarus: authoritarian resilience, social contracts, and patronage in a post-Soviet environment, "Eurasian Geography and Economics" 2014, vol. 55, No. 5, s. 520.

55 R. Coalson, Flexible stagnation: how Lukashenka has held on to power for 25 years in Belarus, RFERL [online], 20 VII 2019 [dostęp: 31 I 2020], dostępny w internecie: $<$ https://www.rferl.org/a/flexible-stagnation-how-lukashenka-has-held-on-to-power-for25-years-in-belarus/30066472.html>.

56 D. Lavnikevič, Sžižennyj i tenevoj. Kak rossijskie gazotrejdery predaût Putina, dsnews. ua [online], 10 VIII 2018 [dostęp: 8 III 2020], dostępny w internecie: https://www. dsnews.ua/economics/szhizhennyy-i-tenevoy-komu-na-karman-rabotaet-tysyachanelegalnyh-09082018220000.

57 Jest to trzecie tego typu centrum obok Bremino-Bruzgi i Bremino-Berestowica. Zob. Â. Romančuk, Beg na meste...; V novyj 2019 god s Bremino grupp! Bremino.by [online], 29 XII 2018 [dostęp: 31 I 2020], dostępny w internecie: <https://bremino.by/ novosti/v-novyy-2019-god-s-bremino-grupp/>.

58 Po stronie rosyjskiej $\mathrm{w}$ tę działalność zaangażowanych jest wielu prominentnych przedstawicieli bloku celno-skarbowego, z którymi walczą zażarcie ich koledzy liczący milionowe straty, jakie z tytułu legalizacji towarów objętych sankcjami ponosi rosyjski budżet. S. Ivaškevič, Kto vo vlasti pokryvaet kontrabandu iz Belarusi v Rossiû? Rassledovanie „Belsata”, Belsat.eu [online], 8 III 2019 [dostęp: 31 I 2020], dostępny w internecie: $<$ https://belsat.eu/ru/programs/kto-vo-vlastipokryvaet-kontrabandu-iz-belarusi-v-rossiyu-rassledovanie-belsata/>. 
szczególny rodzaj mutualizmu w stosunkach rosyjsko-białoruskich i konflikty $\mathrm{w}$ łonie rosyjskiej elity politycznej $\mathrm{w}$ odniesieniu do statusu oraz przyszłości stosunków Rosji z Białorusią, mimo upływu lat i zmniejszającego się znaczenia narracji braterskiej, wciąż sprzyja ciągłości istnienia reżimu Łukaszenki i powstrzymuje istotne zmiany co do statusu prawno-międzynarodowego Białorusi ${ }^{59}$.

\section{Działania Białorusi na rzecz zachowania „strategicznej autonomii” w relacjach z Rosją}

Perspektywa budowy wspólnie z Rosją Państwa Związkowego ma istotne znaczenie z punktu widzenia stabilności białoruskiego reżimu politycznego. Troska Łukaszenki o zachowanie władzy wpływa na stanowisko negocjacyjne Białorusi. Zależność między instytucjonalizacją współpracy z Rosją a konsolidacją białoruskiego modelu rządów autorytarnych ma dość długą tradycję sięgającą połowy lat dziewięćdziesiątych XX w. O ile w początkowym okresie rządów Łukaszenki ścisła współpraca z Rosją i instytucjonalizacja Państwa Związkowego były podstawą strategii legitymizacyjnej reżimu jego władzy, to w chwili obecnej w istotnym stopniu opiera się ona na dystansowaniu się od Rosji, afirmacji białoruskiej suwerenności i sprzeciwie wobec idei pogłębionej integracji. Obecna polityka Rosji stwarza realne zagrożenie dla ciągłości kształtowanego od połowy lat dziewięćdziesiątych białoruskiego modelu społeczno-gospodarczego, a w konsekwencji również dla reżimu Łukaszenki.

Nasilająca się presja integracyjna ze strony Kremla sprzyja więc wzrostowi legitymacji reżimu Łukaszenki, który pozycjonuje się jako ostatni bastion białoruskiej suwerenności i niepodległości. Strategia ta sięga 2002 r. odkąd Łukaszenka skutecznie zaczął „ustawiać się” w charakterze obrońcy Białorusi wobec Rosji ${ }^{60}$. Od tego już momentu łączył podejście

59 W przeszłości Łukaszenka skutecznie rozgrywał na swoją korzyść istniejące napięcia wewnątrz rosyjskiego obozu władzy, które wynikały z odmiennej percepcji roli Białorusi w rosyjskiej polityce zagranicznej i oceny korzyści wynikających z bliskich relacji z Mińskiem (finansowi pragmatycy vs geopolitycy), a także konfliktu interesów z uwzględnieniem kontroli nad aktywami gospodarczymi Białorusi (Sieczyn vs Miedwiediew). Zob. L. Jonavičius, From Russia with love: internal balance of power in Russia and the survival of Lukashenko's regime, "Lithuanian Foreign Policy Review" 2013, vol. 29.

60 A. Klaskovskij, ,, Muhi i kotlety”: Putin gotovit Minsku firmennoe blûdo, Naviny.by [online], 26 IX 2011 [dostęp: 31 I 2020], dostępny w internecie: <https://naviny.by/rubrics/ politic/2011/09/26/ic_articles_112_175234>. 
statokratyczne w zakresie budowy tożsamości narodowej (afirmacja idei suwerenności i niepodległości jako wartości autotelicznych) z elementami etnokulturowymi i polityczno-kulturowymi, które do tej pory były domeną prozachodnich sił opozycyjnych ${ }^{61}$.

Białoruś, w szerszym ujęciu, od dłuższego już czasu zachowywała dystans w stosunku do aktywności Rosji na arenie międzynarodowej, w szczególności w regionie poradzieckim. Rosyjska aneksja Krymu umocniła jedynie poczucie zagrożenia ze strony Kremla. Jeszcze przed wybuchem wojny rosyjsko-gruzińskiej w 2008 r., która unaoczniła gotowość Rosji do użycia siły w celu rozwiązania sporów z sąsiadami i rewizji granic byłych republik radzieckich, Mińsk odebrał sygnały, które wskazywały, że Moskwa nie będzie tolerować w nieskończoność samodzielności Łukaszenki, białoruskiej niepodległości, a w dodatku dotować Białoruś ${ }^{62}$.

Mińsk w swych zabiegach na rzecz zachowania „strategicznej autonomii” dąży do pozyskania zrozumienia Zachodu, lecz biorąc pod uwagę naturę białoruskiego reżimu politycznego może to wydawać się przedsięwzięciem skazanym na porażkę. Z pomocą przyszła tu jednak asertywna polityka Rosji w regionie, która stała się katalizatorem zbliżenia Białorusi z Zachodem. Dynamika stosunku Mińska do Zachodu była skorelowana negatywnie ze stanem relacji z Rosją, ale w jeszcze większym stopniu z jej aktywnością w regionie bliskiej zagranicy. Starania Białorusi zdają się przynosić spodziewany rezultat. W coraz większym stopniu przykuwa ona uwagę Zachodu i wzbudza troskę o jej suwerenność. Autorytarny charakter rządów na Białorusi jest w coraz mniejszym stopniu problemem dla Zachodu. Geostrategiczne uwarunkowania nakazują przymknąć oczy na niedemokratyczny charakter białoruskiego systemu politycznego w obliczu rosnącej presji ze strony Rosji ${ }^{3}$. Na Zachodzie w środowiskach eksperckich ugruntowuje się podejście, że „konsolidacja białoruskiej niepodległości jest ważniejsza niż promowanie demokracji”" ${ }^{44}$.

61 Belorussiâ otkazalas' byt' pridatkom drugoj strany, Lenta.ru [online], 14 VI 2019 [dostęp: 31 I 2020], dostępny w internecie: <https://lenta.ru/news/2019/06/14/pridatok/>.

62 Lukašenko ob'âsnil, počemu oficial'no ne priznal Krym rossijskim, a Abhaziû - nezavisimoj, TUT.BY [online], 3 X 2019 [dostęp: 31 I 2020], dostępny w internecie: <https:// news.tut.by/economics/628354.html>.

63 G.E. Howard, The growing importance of Belarus on NATO's baltic flank, The Jamestown Foundation [online], 2019 [dostęp: 31 I 2020], dostępny w internecie: <https:// jamestown.org/product/the-growing-importance-of-belarus-on-natos-baltic-flank/>.

64 G.V. Ioffe, Two "Non-Russias". Comparing Belarus and Ukraine, "Russia in Global Affairs" [online], 2018, nr 2 [dostęp: 31 I 2020], dostępny w internecie: <https://eng.globalaffairs.ru/number/Two-Non-Russias-19610? fbclid=IwAR3IfUINRqUC4i4cgMUDGwnM23V71Xw1NHb29e-DAwMGzghh08ENRutJhUU>. 
Szczególnego znaczenia nabiera asertywna (zarazem pragmatyczna) postawa Łukaszenki przeciwstawiającego się poszerzaniu wojskowej obecności Rosji na Białorusi. W 2019 r. podkreślił, że sprzeciw wobec rosyjskiej bazy wynika nie z chęci manifestacji suwerenności i niezależności, ale z tego, że Białoruś w ramach współpracy wojskowo-obronnej z Rosją jest zdolna do obrony swojego terytorium ${ }^{65}$. Niechęć wobec obecności rosyjskiej bazy lotniczej, która niewątpliwie przyniosłaby Białorusi dodatkowe korzyści finansowe, wynikała jednak przede wszystkim z obawy przed eskalacją napięcia na linii NATO-Rosja, której ofiarą mogłaby paść Białoruś ${ }^{66}$. W związku z tym Mińsk ostatecznie podjął decyzję o samodzielnej inwestycji w rozwój bezpieczeństwa narodowego i własnego lotnictwa wojskowego, a jesienią 2019 r. do Baranowicz dostarczono 2 z 12 myśliwców Su-30SM ${ }^{67}$.

Jeśli wziąć pod uwagę czynnik społeczno-demograficzny, który mógłby wpłynąć na powodzenie projektu integracyjnego Rosji i Białorusi (dobrowolnego lub wymuszonego), to należy założyć, że w tej sytuacji mniejszość rosyjska na Białorusi nie spełni roli katalizatora. Wynika to z braku przesłanek negatywnych - na Białorusi język rosyjski dominuje w administracji, szkolnictwie, mediach; jego pozycji nie można w żaden sposób porównywać z przypadkiem ukraińskim, co podkreśliła sama rzeczniczka rosyjskiego $\mathrm{MSZ}^{68}$. Brak jest również uwarunkowań pozytywnych w rozumieniu

65 Zdaniem Łukaszenki z czysto militarnego punktu widzenia rozmieszczenia bazy wojsk lotniczych w pobliżu granicy [z wrogim blokiem, tzn. NATO - M.S.] jest błędem. Łukaszenka nie miał nic przeciwko temu, by samoloty zostały rozmieszczone na Białorusi, ale chciał przy tym, aby zostały one podporządkowane białoruskiemu dowództwu. Zob. S. Tarasov, Lukašenko zaâvil, čto emu ne nužnarossijskaâ voennaâ baza, Svobodnaâ Pressa [online], 6 XI 2019 [dostęp: 31 I 2020], dostępny w internecie: <https://svpressa.ru/war21/news/215249/>; T. Mel'ničuk, Lukašenko rezko protiv rossijskoj voennoj bazy $i$ zovet narod $k$ oborone. Čto èto značit?, BBC News | Russkaâ služba [online], 8 XI 2019 [dostęp: 31 I 2020], dostępny w internecie: <https://www.bbc.com/russian/ features-46139216>.

66 A. Golts, Belarus and Russia: military cooperation but with different goals, [w:] Belarusian foreign policy: $360^{\circ}$, red. A. Kudors, The Centre for East European Policy Studies, University of Latvia Press Rīga, 2017.

67 Białoruś: rosyjskie myśliwce zamiast rosyjskiej bazy?, Belsat.eu [online], 14 XI 2019 [dostęp: 31 I 2020], dostępny w internecie: <https://belsat.eu/pl/news/bialorus-rosyjskiemysliwce-zamiast-rosyjskiej-bazy/>.

68 Jak skomentowała Maria Zacharowa: „Język rosyjski ma status oficjalny, zapisany w konstytucji Białorusi. Stosunek do języka rosyjskiego i kultury rosyjskiej, ruskiej [tzn. kultury Rosji, kultury rosyjskiej - red.] na Białorusi nie jest w żaden sposób porównywalny z sytuacją na Ukrainie". Zob. Rosja skomentowała sytuacje językowa na Biatorusi, Belsat.eu [online], 2 III 2019 [dostęp: 31 I 2020], dostępny w internecie: <https:// belsat.eu/pl/news/rosja-skomentowala-sytuacje-jezykowa-na-bialorusi/>. 
obecności znaczącej grupy Rosjan (rosyjskojęzycznych) zainteresowanych integracją z Federacją Rosyjską. Terytorium Białorusi zamieszkuje grupa etnicznych Rosjan odczuwających emocjonalną więź z Rosją. Chociaż mniejszość rosyjska przebywa głównie w miastach wschodniej Białorusi, to jej liczba jest stosunkowo niewielka - 8,2 proc. ogółu ludności (785 tysięcy osób) - i uległa znaczącemu zmniejszenie w stosunku do spisu powszechnego z 1989 r.; wówczas stanowiła około 1 miliona osób (13 proc. populacji $)^{69}$. Trudno znaleźć w tym kraju - zarówno na poziomie społecznym, jak i elit politycznych, czy nawet wojskowych - ,ambasadorów” zbliżenia z Rosją, nawet uwzględniwszy stopień rusyfikacji białoruskiego systemu politycznego ${ }^{70}$.

Jednocześnie Łukaszenka zdecydowanie walczył z wszelkimi przejawami krytyki płynącej ze strony prorosyjskich ośrodków opiniotwórczych działających na Białorusi - włącznie z więzieniem rosyjskich dziennikarzy „szkalujących białoruski naród”; przeciwstawiał się instytucjonalizacji „,partii rosyjskiej”, usuwając z terytorium państwa rosyjskich polityków, którzy tak jak były ambasador Babicz angażowali się w białoruską politykę, naruszali monopol Łukaszenki w obrębie działań politycznych i grozili destabilizacją reżimu politycznego.

Mamy obecnie do czynienia z wyraźną determinacją Łukaszenki, by bronić się przed presją ze strony Kremla. Podejmowane są również próby adaptacji do nadchodzących zmian. Wskazać można m.in. nakaz znalezienia alternatywnych źródeł dostaw ropy, jaki został sformułowany przez Łukaszenkę 31 XII 2019 r., brak zdecydowanych działań (w trakcie ich trwania) ze strony milicji na nielegalne manifestacje przeciwników integracji z Rosją, które odbyły się w dniach 7-8 XII 2019 w Mińsku ${ }^{71}$. Białoruski prezydent dokonał także zmian w swoim najbliższym otoczeniu, powołując na stanowisko szefa prezydenckiej administracji generała KGB Igora Siergiejenko, który odpowiadał w strukturach Komitetu za działalność kontrwywiadowczą i znany był ze swego wrogiego stosunku do rosyjskich agentów wpływu na Białorusi oraz odpowiadał za ich „,czystkę”. Był zarazem lojalnym „członkiem rodziny”

69 Kto zamieszkuje Białoruś, dostępny w internecie [dostęp: 31 I 2020]: <http://belarusfacts. by/p1/belarus/about/population/>; S. M. Eke, T. Kuzio, Sultanism in Eastern Europe: the socio-political roots of authoritarian populism in Belarus, "Europe-Asia Studies" 2000, vol. 52, No. 3, s. 533.

70 G. Ioffe, Avtoritarizm bez oligarhii, „Pro et Contra” 2011, nr 37, s. 31 i n.; A. Shraibman, A brotherly takeover: could Russia annex Belarus?, Carnegie Moscow Center [online], 29 I 2019 [dostęp: 31 I 2020], dostępny w internecie: <https://carnegie.ru/ commentary/78226>.

71 Rossiâ i Belarus': problema integracii, Politkom.ru [online], 9 XII 2029 [dostęp: 31 I 2020], dostępny w internecie: <http://politcom.ru/23641.html>. 
bezpośrednio związanym z najstarszym synem Łukaszenki, Wiktarem ${ }^{72}$. W styczniu 2020 r. sekretarzem Rady Bezpieczeństwa został mianowany dotychczasowy minister obrony narodowej Andrej Raukou ${ }^{73}$. Postawa samego Łukaszenki i elit białoruskich broniących się przed integracją z Rosją jest całkiem zrozumiała - nie chcą dzielić się wpływami i prestiżem z rosyjskimi oligarchami czy kastą urzędniczą, oraz tracić wpływy w swoich domenach. $Z$ całą pewnością białoruska nomenklatura woli, wzorem państw regionu, uwłaszczyć się na własnych zasadach, niż dzielić się profitami z przyszłej prywatyzacji z elitami polityczno-gospodarczymi Rosji.

\section{Białoruś to nie Ukraina... Stosunek białoruskiego społeczeństwa do integracji z Rosją}

Abstrahując od ambiwalentnego stanowiska rosyjskiej elity politycznej w odniesieniu do perspektyw współpracy z Białorusią, a także zdecydowanej wrogości Łukaszenki wobec idei konieczności dzielenia się władzą z Moskwą, na drodze do dalszej integracji obu państw stoi w tej kwestii negatywne stanowisko białoruskiego społeczeństwa. Rozbudzonym nastrojom proniepodległościowym wśród Białorusinów, które rozwijają się nawet bez stymulacji ze strony państwa, towarzyszy również przeświadczenie o niskiej atrakcyjności modelu rozwoju społeczno-gospodarczego Rosji postrzeganego jako oligarchiczny, niesprawiedliwy, skorumpowany i agresywny ${ }^{74}$. Na niekorzyść planów integracyjnych oddziałują również zmiany demograficzne (pokoleniowe) dokonujące się w białoruskim społeczeństwie. Ponad połowa jej mieszkańców nie pamięta okresu istnienia Związku Radzieckiego, a niepodległa Białoruś jest dla nich czymś oczywistym i naturalnym ${ }^{75}$.

Białoruskie społeczeństwo w kwestii stosunków z Rosją jest podzielone. Jeden z ostatnich sondaży Białoruskiej Pracowni Analitycznej (BPA) dotyczący stosunku Białorusinów do międzynarodowej pozycji Białorusi pochodzi z września 2019 r. Jego wyniki jednoznacznie wskazują, że większość

72 NEZYGAR'-Telegram, 5 XII 2019 [dostęp: 31 I 2020], dostępny w internecie: <https:// tlg.name/s/russica2/21596>.

73 Zmiany w strukturach siłowych. - Jesteśmy ludźmi wojska-mówi Łukaszenka, Belsat.eu [online], 20 I 2020 [dostęp: 31 I 2020], dostępny w internecie: $<$ https://belsat.eu/pl/news/zmianyw-bialoruskich-strukturach-silowych-jestesmy-ludzmi-wojska-mowi-lukaszenka/>.

74 Wskaźniki percepcji korupcji są niemal dwukrotnie niższe w przypadku Białorusi w porównaniu z Rosją. L. Merežkovskij, Začem Belarusi soûz s Rossiej, Česnok [online], 27 IX 2019 [dostęp: 31 I 2020], dostępny w internecie: <https://4esnok.by/mneniya/ zachem-belarusi-sojuz-s-rossiej/>.

75 Â. Romančuk, Beg na meste... 
Białorusinów (54,5 proc.) uważa, iż sojusz z Rosją będzie dla nich korzystniejszy niż ten zbudowany z Unią Europejską, o czym przekonanych było 25 proc. badanych. W stosunku do 2018 r. o 9 proc. zmniejszyła się liczba zwolenników aliansu z Rosją ${ }^{76}$. W latach 2016-2017 zwolenników sojuszu z Rosją było około 64 proc., ścisłych związków z UE oczekiwało w 2016 r. 19 proc. Białorusinów, a w 2017 r. - zaledwie 14 proc. ${ }^{77}$ Wola większości Białorusinów, by podtrzymywać sojusz z Rosją, nie oznaczała automatycznie zaakceptowania integracji obu państw czy zgody na aneksję Białorusi przez Rosję, tj. realizację „modelu krymskiego”, polegającego na przyjęciu jej w skład Federacji Rosyjskiej na prawach podmiotu składowego.

Białorusini nie obawiają się, że Rosja w stosunku do ich kraju powtórzy „manewr krymski”. W 2017 r. perspektywa aneksji Białorusi lub części jej terytorium wydawała się niewiarygodna dla 68,3 proc. badanych osób, a taką możliwość dopuszczało jedynie 14,1 proc. ${ }^{78} \mathrm{~W} 2019$ r. prawdopodobieństwo podobnego scenariusza zmniejszyło się według Białorusinów jeszcze bardziej, gdyż aż 72 proc. odrzucało myśl, że Rosja może być agresywna w swych roszczeniach terytorialnych wobec Białorusi ${ }^{79}$. Istotnego poza tym znaczenia nabrało niezaangażowanie się Unii Europejskiej i jej bezradność w obliczu działań Rosji, gdy sytuacja społeczno-polityczna i gospodarcza Ukrainy ulegała pogorszeniu. Trwałe i ugruntowane jest także przeświadczenie, że Rosjanie, Białorusini i Ukraińcy stanowią trzy części wspólnoty ogólnoruskiej. Wzrost napięcia w stosunkach rosyjsko-białoruskich - któremu towarzyszyła presja ze strony Kremla, aby zakończyć negocjacje w sprawie map drogowych tzw. pogłębionej integracji - oraz antyzjednoczeniowe manifestacje na Białorusi spowodowały wyraźne załamanie się nastrojów prorosyjskich w tym kraju. Białoruska Pracownia Analityczna odnotowała w grudniu 2019 r. najniższy - od momentu aneksji Krymu - poziom poparcia dla związku z Rosją (40,4 proc.). Jednocześnie zaobserwowano bezprecedensowy poziom akceptacji zbliżenia z Unią Europejską (32 proc.) ${ }^{80}$.

76 V Belarusi padaet čislo storonnikov soûza s Rossiej-minus 9 punktov za god, TUT.BY [online], 2 X 2019 [dostęp: 31 I 2020], dostępny w internecie: <https://news.tut.by /economics/655706.html>.

77 Opros: 7\% belorusov hotât vizy s Rossiej, každyj šestoj hočet ob"edineniâ dvuh stran, TUT.BY [online], 17 III 2017 [dostęp: 31 I 2020], dostępny w internecie: <https://news. tut.by /economics/543469.html>.

78 Tamże.

79 Tamże.

80 P. Rudkovskij, Belorusy stali men'še simpatizirovat' Rossii. No Moskvy v golovah ne ubavilos', Naviny.by [online], 15 II 2020 [dostęp: 9 III 2020], dostępny w internecie: $<$ https://naviny.by/article/20200215/1581750204-belorusy-stali-menshe-simpatizirovatrossii-no-moskvy-v-golovah-ne>. 


\section{Scenariusze rozwoju stosunków rosyjsko-białoruskich}

Z punktu widzenia perspektyw rozwoju stosunków rosyjsko-białoruskich najważniejszego znaczenia - moim zdaniem - nabiera determinacja stron w zakresie utrzymania/zmiany istniejącego modelu stosunków dwustronnych. Przyjmując założenie, że stanowi ona krytyczną niewiadomą w odniesieniu do budowy scenariuszy i odwołując się do metody ideacyjnej w trakcie realizacji której można wykorzystać oś continuum determinacji, gdzie dwa skrajne końce wyznaczają wysoki i niski poziom determinacji, jest możliwe skonstruowanie czterech scenariuszy będących wynikiem kombinacji poziomów determinacji obydwu stron.

Tabela 1. Scenariusze rozwoju stosunków rosyjsko-białoruskich $\mathrm{z}$ uwzględnieniem poziomu determinacji stron w zakresie zmiany/ utrzymania istniejącego modelu relacji

\begin{tabular}{|c|c|c|c|}
\hline & \multicolumn{2}{|c|}{$\begin{array}{l}\text { Stopień determinacji Rosji w odniesieniu } \\
\text { do zmiany istniejącego modelu relacji z Białorusią }\end{array}$} \\
\hline & & wysoki & niski \\
\hline \multirow{2}{*}{$\begin{array}{l}\text { Gotowość Białorusi } \\
\text { do utrzymania } \\
\text { istniejącego modelu } \\
\text { relacji z Rosją }\end{array}$} & wysoka & otwarty konflikt & status quo \\
\hline & niska & ,zintegrowanie” Białorusi & „pełzająca integracja” \\
\hline
\end{tabular}

Pierwszy scenariusz, zaczynając od prawego dolnego rogu (,pełzająca integracja”) zakłada niski poziom zainteresowania Rosji faktyczną budową wspólnego z Białorusią Państwa Związkowego. W dalszym ciągu podejmowane są jednak próby ograniczenia strat dla rosyjskiego budżetu przez unifikację systemów celno-podatkowych Rosji i Białorusi. Towarzyszy temu gotowość Białorusi do zaakceptowania części propozycji rosyjskich wynikających z założeń pogłębionej integracji. Ich realizacja jest jednak rozciągnięta w czasie i co chwilę znajduje się w martwym punkcie. Łukaszenka decyduje się na udział w procesie negocjacyjnym, aby uniknąć wyprzedaży kolejnych przedsiębiorstw rosyjskim oligarchom.

Drugi ze scenariuszy obejmuje z jednej strony wysoką determinację strony białoruskiej, żeby utrzymać istniejące zasady współpracy z Rosją głównie w zakresie polityki energetycznej. Strona rosyjska traci zainteresowania pogłębioną integracją - status quo jest zachowane dzięki wysiłkom wpływowych przedstawicieli rosyjskich elit biznesowych, którzy zyskują udziały w kolejnych przedsiębiorstwach białoruskich. Frakcja siłowa zaangażowana 
jest w innych regionach świata i przygotowuje się do zmiany wewnątrz reżimu władzy w Rosji. Białoruś pozostaje niepodległa, a Łukaszenka zachowuje władzę po następnych wyborach prezydenckich, lecz jej podstawowe podmioty gospodarcze znajdują się w rękach rosyjskich oligarchów.

Trzeci scenariusz dotyczy sytuacji, w której główne grupy rosyjskiej elity władzy dochodzą do porozumienia w kwestii przyszłego statusu Białorusi. Struktury siłowe, liberałowie i wpływowi przedstawiciele elit biznesowych podejmują decyzję o wchłonięciu Białorusi - platformą integracji staje się Państwo Związkowe. Powstają konstytucja związkowa ponadnarodowego organu władzy państwowej i wspólne centrum emisji pieniądza - czyli Białoruś została przez Rosję ,zintegrowana”. Łukaszenka w zamian za możliwość udziału we władzach Państwa Związkowego podporządkowuje się dyktatowi Rosji, która sięga w celu ograniczenia białoruskiej ,strategicznej autonomii" po narzędzia szantażu energetycznego i politycznego. Wysiłki Łukaszenki, by znaleźć alternatywne źródła dostaw ropy, nie powstrzymały kryzysu społeczno-gospodarczego - reżim stanął w obliczu masowych protestów społecznych, a intensyfikacja współpracy z Zachodem (w tym z NATO) wywołała wrogą reakcję rosyjskich resortów siłowych.

W przypadku czwartego scenariusza strony dążą do konfrontacji, która kończy się otwartym konfliktem. Łukaszenka stanął w obliczu bezprecedensowej i bezkompromisowej presji ze strony Kremla; podjął jednak decyzję, że jedyną szansą utrzymania władzy będzie walka z rozszerzającymi się wpływami Rosji zarówno tymi proponowanymi w ramach pogłębionej integracji, jak i będącymi skutkiem zaangażowania wpływowych rosyjskich oligarchów. Białoruski prezydent decyduje się wcielić w życie swe dotychczasowe obietnice, w myśl których nie pogrzebie białoruskiej państwowości i prosi o pomoc państwa Zachodu, deklarując przy tym europejskie „powołanie". Białoruś staje się areną antyrosyjskich manifestacji, w których uczestniczą aktywiści z Ukrainy i państw bałtyckich, a ona sama przekształca się w antyRosję. Rosja odpowiada blokadą energetyczną, zaczyna otwarcie dążyć do obalenia Łukaszenki. Konflikt ulega eskalacji w wyniku zorganizowanego przez Kreml przewrotu pałacowego.

\section{Podsumowanie}

Wbrew pojawiającym się opiniom ze strony publicystów podejmujących problematykę stosunków rosyjsko-białoruskich i kasandrycznym przepowiedniom samego Łukaszenki rok 2019 nie stał się przełomowy w odniesieniu 
do zmiany istniejącego modelu stosunków rosyjsko-białoruskich. Białoruś w osobie Aleksandra Łukaszenki - zdecydowana jest bronić ukształtowanego jeszcze w połowie lat dziewięćdziesiątych ubiegłego wieku formatu relacji dwustronnych i nie akceptuje propozycji Kremla w zakresie pogłębionej integracji. Z punktu widzenia stabilności i ciągłości reżimu politycznego propozycje rosyjskie stanowią poważne wyzwanie dla elit politycznych, biznesowych i administracyjnych skupionych wokół Łukaszenki. Dalsza integracja z Rosją, nawet jeśli ograniczyłaby się do kwestii finansowo-gospodarczych, byłaby z ich punktu widzenia materialną i prestiżową katastrofą. Strona białoruska, mimo wyraźnie gorszej pozycji przetargowej, odrzuca propozycje rosyjskie, stojąc na stanowisku, że Kreml nie zdecyduje się na rozwiązanie siłowe, ani na wariant krymski (interwencję militarną), ani wariant pomarańczowy (interwencję polityczną). Białoruski obóz władzy jest spójny w wymiarze stosunku do integracji z Rosją, ma za sobą również poparcie większości białoruskiego społeczeństwa.

Rosja dysponuje szerokim spektrum negatywnych narzędzi oddziaływania na Mińsk (szantaż energetyczny, destabilizacja sytuacji politycznej i społeczno-gospodarczej), ale nie posiada narzędzi pozytywnych. Model rozwoju społeczno-gospodarczego i politycznego Rosji nie jest atrakcyjny z punktu widzenia Białorusinów. Odczuwalny jest również brak spójności wewnętrznej rosyjskiego obozu władzy w odniesieniu do przyszłości Białorusi. Słabość Moskwy jest w tej sytuacji atutem Białorusi. Podobnie rzecz się ma ze stosunkiem Rosjan do integracji z Białorusią, która ich zdaniem nie jest działaniem koniecznym. W chwili obecnej można przyjąć, że Rosję interesuje zmiana dotychczasowego modelu relacji dwustronnych, ale w stopniu zawężonym, przede wszystkim w zakresie ograniczenia strat finansowych wynikających z powodu dotowania białoruskiej gospodarki i lekceważenia przez Mińsk istniejących zobowiązań w obszarze celno-podatkowym. Koncepcja pogłębionej integracji, obejmująca m.in. unifikację systemów podatkowych i integrację rynku energii, ograniczyłaby straty rosyjskiego budżetu. Brak jest jednak wyraźnej (znaczącej) determinacji Kremla w sprawie zmiany istniejącego statusu prawno-międzynarodowego Białorusi. Świadectwem tego jest powstrzymywanie się przed zmianą obecnego układu stosunków i wprowadzaniem mechanizmów siłowych. Białoruś przedstawia bowiem dla Rosji wartość jako całość, a jej destabilizacja nie jest konieczna, ponieważ w przeciwieństwie do Gruzji i Ukrainy nie zgłasza ona chęci członkostwa w strukturach europejskich i euroatlantyckich. Próba 
zastosowania wobec Białorusi rozwiązań siłowych (militarnych lub politycznych) grozi przekształceniem jej w kolejne, po Ukrainie i Gruzji, wrogie Rosji państwo obszaru poradzieckiego.

W stosunkach rosyjsko-białoruskich, jak pokazano w toku analizowanego tu problemu, mamy do czynienia z kombinacją wysokiej - po stronie Białorusi oraz niskiej - w przypadku Rosji determinacji do zmiany istniejącego modelu stosunków dwustronnych. W związku z tym za najbardziej prawdopodobny scenariusz należy uznać utrzymania istniejącego modelu relacji, ale przy większych kosztach, które z tego powodu będzie ponosić Białoruś. Nie można jednak wykluczyć, że poziom determinacji obydwu podmiotów będzie ulegał zmianie w czasie i pod wpływem nowych bodźców (informacji finansowych, działań aktorów zewnętrznych, fragmentaryzacji ośrodków decyzyjnych). Rosja może zacząć stosować bardziej zdecydowane metody (wciąż jednak nie siłowe), aby dalej podporządkowywać Białoruś, a Białoruś ,,skapituluje" w obliczu kurczących się zasobów, nadciągającej groźby kryzysu społeczno-gospodarczego i politycznego, szczególnie w ważnym dla Łukaszenki roku wyborczym, co zakończy się wejściem na ścieżkę ,pełzającej integracji”. Ta oznaczać będzie dla Białorusi utratę ,strategicznej autonomii” i suwerenności - jednak nie doprowadzi do powstania wspólnego państwa. Jeśli jednak Białoruś nie skapituluje i będzie w coraz większym stopniu otwierać się na współpracę z Zachodem i Chinami, a Kreml rozdrażniony rosnącą międzynarodową aktywnością Mińska sięgnie po środki siłowo-polityczne, np. sabotaż polityczny, to można spodziewać się otwartego konfliktu i przekształcenia Białorusi w ,antyRosję” na podobieństwo Ukrainy i Gruzji.

Nie należy natomiast sądzić, by skrajny scenariusz - wchłonięcie Białorusi przez Rosję w toku procesu pogłębionej integracji (,zintegrowanie” Białorusi) - doczekał się szybkiej realizacji. Koszty absorbcji Białorusi byłby dla Rosji znaczne - eksploatacja Białorusi jako państwa nominalnie niepodległego, samodzielnie troszczącego się o wpływy do budżetu, jest przedsięwzięciem bardziej opłacalnym. Co więcej, w samej Rosji wciąż obecna jest wpływowa grupa przedstawicieli elit biznesowych zainteresowanych utrzymaniem administracyjno-prawnego status quo Białorusi, które w chwili obecnej umożliwia im czerpanie zysków ze współpracy z Łukaszenką. Zmiany $\mathrm{w}$ rosyjskim systemie politycznym związane z nowelą konstytucyjną i rozpoczęciem dyskusji na temat przyszłości reżimu władzy w Rosji po 2024 r. również nie sprzyjają podejmowaniu wiążących decyzji dotyczących przyszłości stosunków z Białorusią. 


\section{Bibliografia}

Balmaceda M.M., Energy policy in Belarus: authoritarian resilience, social contracts, and patronage in a post-soviet environment, "Eurasian Geography and Economics" 2014, vol. 55, No. 5, s. 520.

Belorussiâ otkazalas' byt' pridatkom drugoj strany, Lenta.ru [online], 14 VI 2019 [dostęp: 31 I 2020], dostępny w internecie: <https://enta.ru/news/2019/06/14/pridatok/>.

Bernstein S., Lebow N., Gross Stein J., Weber S., God gave physics the easy problems: adapting social science to an unpredictable world, "European Journal of International Relations" 2000, vol. 7, No. 1.

Białoruś czekaja ciężkie rozmowy na temat cen ropy naftowej, Belsat.TV [online], 10 VIII 2018 [dostęp: 31 X 2020], dostępny w internecie: <https://belsat.eu/pl/news/bialorus-czekajaciezkie-rozmowy-na-temat-cen-ropy-naftowej/>.

Białoruś: rosyjskie myśliwce zamiast rosyjskiej bazy?, Belsat.eu [online], 14 XI 2019 [dostęp: 31 I 2020], dostępny w internecie: <https://belsat.eu/pl/news/bialorus-rosyjskiemysliwce-zamiast-rosyjskiej-bazy/>.

Bočarova S., Muhametšina E., Začem Putin smenil posla v Belorussii, Vedomosti, 1 V 2019.

Carik Û., Družba bez nefti, Riddle [online], 23 I 2020 [dostęp: 31 I 2020], dostępny w internecie: $<$ https://www.ridl.io/ru/druzhba-bez-nefti/>.

Carik Û., Sočinskij sammit: Lukašenko i Putin ostaûtsâ „pri svoem”, Riddle [online], 16 XII 2019 [dostęp: 31 I 2020], dostępny w internecie: <https://www.ridl.io/ru/ sochinskij-sammit-lukashenko-i-putin-ostajutsja-pri-svoem/>.

Cialpuk J., Przyczyna zjednoczeniowego impasu: rodzina Łukaszenki traci na integracji z Rosją?, Belsat.eu [online], 4 X 2020 [dostęp: 31 I 2020], dostępny w internecie: <https:// belsat.eu/pl/news/glowna-przyczyna-zjednoczeniowego-impasu-rodzina-lukaszenki-tracina-integracji-z-rosja/>.

Coalson R., Flexible stagnation: how Lukashenka has held on to power for 25 years in Belarus, RFERL [online], 20 VII 2019 [dostęp: 31 I 2020], dostępny w internecie: <https://www. rferl.org/a/flexible-stagnation-how-lukashenka-has-held-on-to-power-for-25-years-inbelarus/30066472.html>.

Drakohrust Û., Kak Putin ne stal belorusom. Peripetii sbliženiâ sosedej, Radio Svoboda [online], 5 IX 2019 [dostęp: 24 XI 2019], dostępny w internecie: <https://www.svoboda.or$\mathrm{g} / \mathrm{a} / 30142580 . \mathrm{html}>$.

Drakohrust Û., Moskovskaâ igra Vladimira Makeâ, TUT.BY [online], 1 X 2019 [dostęp: 31 I 2020], dostępny w internecie: <https://news.tut.by/economics/655613.html>.

Eberhardt A., Gra pozorów. Stosunki rosyjsko-białoruskie 1991-2008, PISM, Warszawa 2008.

Eke S.M., Kuzio T., Sultanism in Eastern Europe: the socio-political roots of authoritarian populism in Belarus, "Europe-Asia Studies" 2000, vol. 52, No. 3.

Golts A., Belarus and Russia: military cooperation but with different goals, [w:] Belarusian foreign policy: $360^{\circ}$, red. A. Kudors, The centre for East European policy studies, University of Latvia Press Rīga 2017.

Howard G.E., The growing importance of Belarus on NATO's baltic flank, The Jamestown Foundation [online], 2019 [dostęp: 31 I 2020], dostępny w internecie: $<$ https://jamestown. org/product/the-growing-importance-of-belarus-on-natos-baltic-flank/>. 
Ioffe G., At second Minsk dialogue forum, Belarus seeks to redefine its reputation, "Eurasia Daily Monitor", vol. 16, No. 145 [online], 21 I 2019 [dostęp: 31 I 2020], dostępny w internecie: $<$ https://jamestown.org/program/at-second-minsk-dialogue-forum-belarus-seeksto-redefine-its-reputation/>.

Ioffe G., Avtoritarizm bez oligarhii, „Pro et Contra” 2011, nr 37.

Ioffe G.V., Two "non-Russias". Comparing Belarus and Ukraine, "Russia in Global Affairs" 2018, nr 2 [online], [dostęp: 31 I 2020], dostępny w internecie: <https://eng.globalaffairs. $\mathrm{ru} /$ number/Two-Non-Russias-19610?fbclid=IwAR3IfUINRqUC4i4cgMUDGwnM23V7 1Xw1NHb29e-DAwMGzghh08ENRutJhUU>.

Ivaškevič S., Kto vo vlasti pokryvaet kontrabandu iz Belarusi v Rossiû? Rassledovanie „Belsata”, Belsat.eu [online], 8 III 2019 [dostęp: 31 I 2020], dostępny w internecie: $<$ https://belsat.eu/ru/programs/kto-vo-vlasti-pokryvaet-kontrabandu-iz-belarusi-v-rossiyurassledovanie-belsata/>.

Jonavičius L., From Russia with love: internal balance of power in Russia and the survival of Lukashenko's regime, "Lithuanian Foreign Policy Review" 2013, vol. 29.

Klaskovskij A., Lukašenko i Putin vrâd li vyp'ût samogonki pered Novym godom. Kreml'

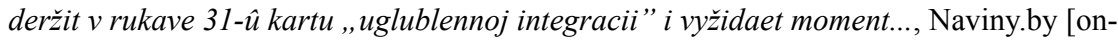
line], 26 XII 2019 [dostęp: 21 I 2020], dostępny w internecie: <https://naviny.by/article/20191226/1577363713-lukashenko-i-putin-vryad-li-vypyut-samogonki-pered-novym-godom>.

Klaskovskij A., Vojny čužie i svoi. Medvedev brosil kamen'v ogorod Lukašenko i polučil otvetku, Naviny.by [online], 5 XI 2019 [dostęp: 31 I 2020], dostępny w internecie: $<$ https://naviny.by/article/20191105/1572932516-voyny-chuzhie-i-svoi-medvedev-brosil-kamen-v-ogorod-lukashenko-i>.

Klinke I., Geopolitical narratives on Belarus in contemporary Russia, "Perspectives" 2008, vol. 16, No. 1.

Kozak ne stal obsuždat's belorusskoj delegaciej skidku na gaz, Interfaks [online], 11 XII 2018 [dostęp: 24 XI 2019], dostępny w internecie: <https://www.interfax.ru/russia/641836>.

Kozlov D., Uporstvo, dostojnoe neftânogo primeneniâ, „Kommersant"”, 14 I 2020.

Konservativnyj i prodvinutyj. Medvedev rasskazal o dvuh scenariâh integracii s Belarus' $\hat{u}$, TUT.BY [online], 13 XII 2018 [dostęp: 24 XI 2019], dostępny w internecie: <https://news. tut.by/economics/619120.html>.

Kto zamieszkuje Białoruś, dostępny w internecie [dostęp: 31 I 2020]: <http://belarusfacts.by/ $\mathrm{pl} /$ belarus/about/population/>.

Levinson A., Rossiâ bez Belorussii, Vedomosti, 20 I 2020.

Lukašenko ob"âsnil, počemu oficial'no ne priznal Krym rossijskim, a Abhaziû - nezavisimoj, TUT.BY [online], 3 X 2019 [dostęp: 31 I 2020], dostępny w internecie: <https://news. tut.by/economics/628354.html>.

Eukaszenka kazat kupować ropę spoza Rosji, Belsat.eu [online], 1 I 2020 [dostęp: 31 I 2020], dostępny w internecie: $<$ https://belsat.eu/pl/news/lukaszenka-kazal-kupowac-rope-spoza-rosji/>.

Mel'ničuk T., Lukašenko rezko protiv rossijskoj voennoj bazy i zovet narod k oborone. Čto èto značit?, BBC News | Russkaâ služba [online], 8 XI 2019 [dostęp: 31 I 2020], dostępny w internecie: $<$ https://www.bbc.com/russian/features-46139216>.

Merežkovskij L., Začem Belarusi soûz s Rossiej, Česnok [online], 27 IX 2019 [dostęp: 31 I 2020], dostępny w internecie: $<$ https://4esnok.by/mneniya/zachem-belarusi-sojuz-s-rossiej/>. 
Merežkovskij L., Začem rossijskie èlity raskačivaût ,, lodku” belorusskoj stabil'nosti, Česnok [online], 11 X 2019 [dostęp: 31 I 2020], dostępny w internecie: <https://4esnok.by/ mneniya/rossijskie-elity-raskachivajut-belarus/>.

MID Belorussii obvinil rossijskogo posla v popytke razrušit' otnošeniâ Moskvy i Minska, TASS [online], 19 IV 2019 [dostęp: 31 I 2020], dostępny w internecie: <https://tass.ru/ mezhdunarodnaya-panorama/6355862>.

Mir v XXI veke: prognoz razvitiâ meždunarodnoj obstanovki po stranam i regionam: monografiâ, red. M.V. Aleksandrova, O.E. Rodionova, MGIMO-Universitet, Moskwa 2018.

NEZYGAR' - Telegram, 5 XII 2019 [dostęp: 31 I 2020], dostępny w internecie: <https://tlg. name/s/russica2/21596>.

Opros: 7\% belorusov hotât vizy s Rossiej, každyj šestoj hočet ob"edineniâ dvuh stran, TUT.BY [online], 17 III 2017 [dostęp: 31 I 2020], dostępny w internecie: <https://news.tut.by/economics/543469.html>.

Posol Babič: nikto nikogda ne predlagal Belarusi vstupit'v sostav Rossii, Naviny.by [online], 14 III 2019 [dostęp: 31 I 2020], dostępny w internecie: <https://naviny.by/article /20190314/1552570803-posol-babich-nikto-nikogda-ne-predlagal-belarusi-vstupit-v-sostav-rossii>.

Posol Rossii prokommentiroval slova Lukašenko o real'noj stoimosti Belaès, TASS [online] 19 IV 2019 [dostęp: 31 I 2020], dostępny w internecie: <https://tass.ru/ekonomika/6354766>.

Proekt Konstitucionnogo akta Soûznogo gosudarstva, Postoânnyj Komitet Soûznogo gosudarstva [online], 14 IV 2005 [dostęp: 31 I 2020], dostępny w internecie: <https://www.postkomsg.com/news/various/170103/>.

Romančuk Â., Beg na meste - obŝeprimirâûse. Âroslav Romančuk o tom, počemu anšlûs Belarusi ne sostoitsâ, The Insider [online], 8 XII 2019 [dostęp: 21 I 2020], dostępny w internecie: $<$ https://theins.ru/opinions/191709>.

Rossiâ i Belarus': problema integracii, Politkom.ru [online], 9 XII 2029 [dostęp: 31 I 2020], dostępny w internecie: $<$ http://politcom.ru/23641.html>.

Rossia i Belorussiâ: novyj format integracii?, Vserossijskij centr izučeniâ obŝestvennogo mneniâ (VCIOM) [online], 2 IV 2019 [dostęp: 31 I 2020], dostępny w internecie: <https:// wciom.ru/index.php?id=236\&uid=9634> .

Rosja skomentowała sytuacje językowa na Biatorusi, Belsat.eu [online], 2 III 2019 [dostęp: 31 I 2020], dostępny w internecie: <https://belsat.eu/pl/news/rosja-skomentowalasytuacje-jezykowa-na-bialorusi/>.

Rosyjski gaz dla Białorusi zagwarantowany do marca, Belsat.eu [online], 1 X 2020 [dostęp: 31 I 2020], dostępny w internecie: <https://belsat.eu/pl/news/rosyjski-gaz-dla-bialorusizagwarantowany-do-marca/?fbclid=IwAR2bezHd7CwC-8KIXPO70YqJzuthsMRlgxZon $\mathrm{KqQgX1LmcW6j83MIcKCXJQ> \text {. }}$

Rumas i Medvedev progulâlis' po Brestskoj kreposti, no po nefti i vizam ne dogovorilis', TUT.BY [online], 13 XII 2018 [dostęp: 24 XI 2019], dostępny w internecie: <https://news.tut.by/ economics/619111.html>.

Rudkovskij P., Belorusy stali men 'še simpatizirovat'Rossii. No Moskvy v golovah ne ubavilos', Naviny.by [online], 15 II 2020 [dostęp: 9 III 2020], dostępny w internecie: <https://naviny.by/article/20200215/1581750204-belorusy-stali-menshe-simpatizirovat-rossii-no-moskvy-v-golovah-ne>. 
Samorukov M., Pogloŝenie, kotorogo net. Počemu Kreml' ne možet vybit'ustupki iz Lukašenko, Moskovskij Centr Karnegi [online], 9 XII 2019 [dostęp: 31 I 2020], dostępny w internecie: $<$ https://carnegieendowment.org/publications/80528>.

Shraibman A., A brotherly takeover: could Russia annex Belarus?, Carnegie Moscow Center [online], 29 I 2019 [dostęp: 31 I 2020], dostępny w internecie: <https://carnegie.ru/ commentary/78226>.

Shraibman A., The house that Lukashenko built: the foundation, evolution, and future of the belarusian regime, Carnegie Moscow Center [online], 12 IV 2019 [dostęp: 24 XI 2019], dostępny w internecie: <https://carnegie.ru/2018/04/12/house-that-lukashenko-builtfoundation-evolution-and-future-of-belarusian-regime-pub-76059>.

Sivitsky A., Belarus-Russia: from a strategic deal to an integration ultimatum, "Russia Foreign Policy Papers" [online], 16 XII 2019 [dostęp: 21 I 2020], dostępny w internecie: <https://www. fpri.org/article/2019/12/belarus-russia-from-a-strategic-deal-to-an-integration-ultimatum/>.

Solov'ev V., Aleksandr Lukašenko skazal meždu strok, „Kommersant"”, 15 XII 2018, nr 232.

Solov'ev V., Krymskaâ vesna teper' $i$ v Minske, „Kommersant"”, 19 III 2019.

Struktury Mihaila Gucerieva načali postavki nefti v Belorussiû, Interfax [online], 14 I 2020 [dostęp: 31 I 2020], dostępny w internecie: <https://www.interfax.ru/business/691170>.

Tarasov S., Lukašenko zaâvil, čto emu ne nužnarossijskaâ voennaâ baza, Svobodnaâ Pressa [online], 6 XI 2019 [dostęp: 31 I 2020], dostępny w internecie: $<$ https://svpressa.ru/war21/ news/215249/>.

Tsarik Y., Belarus and Russia: on the evolution of a „hybrid Union”, Riddle [online], 19 XI 2018 [dostęp: 31 I 2020], dostępny w internecie: <https://www.ridl.io/en/ belarus-and-russia-on-the-evolution-of-a-hybrid-union/>.

Tsarik Y., Vasa L., Foreign policy challenges for Belarus since 2014 and their domestic dimension, KKI Policy Brief, E-2019/33, Institute for Foreign Affairs and Trade, Budapeszt 2019.

V Belarusi padaet čislo storonnikov soûza s Rossiej-minus 9 punktov za god, TUT.BY, 2 X 2019 [dostęp: 31 I 2020], dostępny w internecie : <https://news.tut.by/economics/655706.html>.

Vernidub A., Putin zabral u Lukašenko kotlety s muhami, „Gazeta.ru” [online], 20 VI 2002 [dostęp: 24 XI 2019], dostępny w internecie: <https://www.gazeta.ru/2002/06/20/putinzabralu.shtml>.

Vnovyj 2019 god s Bremino grupp!, Bremino.by [online], 29 XII 2018 [dostęp: 31 I 2020], dostępny w internecie: <https://bremino.by/novosti/v-novyy-2019-god-s-bremino-grupp/>. 